\title{
Making Connections, Imagining New Worlds: Women, Writing, and Resistance in Paris, 1897-1910
}

\author{
by
}

Natalie Hunter

A thesis submitted to the Faculty of Graduate and Postdoctoral Affairs in partial fulfillment of the requirements for the degree of

\author{
Master of Arts
}

in

History

Department of History

Carleton University

Ottawa, Ontario

(C) 2016, Natalie Hunter 


\begin{abstract}
This thesis examines two groups of women who lived and wrote in fin-de-siècle Paris. Marguerite Durand and the contributors to La Fronde used their writing to invade the male sector of journalism and prove they were capable of doing what men could, but doing it for women and without any men involved. Natalie Barney and Renée Vivien used poetry and theatre to remake Sappho's tradition in a way that prioritized her desire for women and her centrality to Lesbos's community of women to challenge sexological discourses that posited their own desires as isolating and corrupt. These case studies, taken together for the first time, suggest new lines of historical inquiry into women and how they used different types of writing in resistance to normative discourses that restricted them and their lives in Paris between 1897 and 1910.
\end{abstract}




\section{Acknowledgements}

I am incredibly indebted to Dr. Susan Whitney for her endless support and insight during this project. Thank you for guiding me in the right direction, keeping me motivated, helping me work through the difficult aspects, and constantly encouraging me to do my best possible work. Your supervision and advice has been essential in helping me clarify my research and has inspired me throughout the duration of my project. Without your help and incredible insight, I would not have been able to do this.

Thank you also to Dr Jennifer Evans, Dr Jodie Medd, and Dr Sonya Lipsett-Rivera for all of your astute questions and commentary during my examination, and for the truly enjoyable discussion. I also owe a debt of gratitude to Joan White for all her tireless help; be it with course registration, travel bursaries, or deadlines.

I would also like to thank the staff of the Sterling Memorial Library and Beinecke Rare Books Library at Yale University for their assistance and kindness as I used their resources.

Many thanks are also due to Emily Cuggy, Laura Hochban, and Sara McGillivray. Your friendship and support has made it possible for me to complete this project and I can't thank you enough for your laughter and light. Thanks for letting me ramble, for the jokes, references, and procrastination spirals - and, of course, the cackling!

Last, but certainly not least, I owe an enormous debt of gratitude to my family. To Shelley Smith, Carman Carroll, Monty Hunter, and Andrea Brennan-Hunter: thank you for helping me work through my ideas, letting me vent about writer's block, and helping me relax. To Becca Carroll, Ian Waugh, Sue Cadman, Rick Cadman, Madeline Hunter, and Colin Hunter: your support throughout this project has meant more than I could ever express. I love you all. 


\section{Table of Contents}

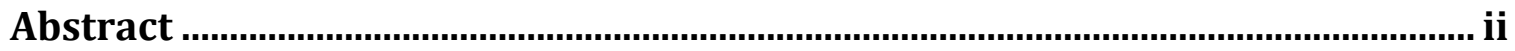

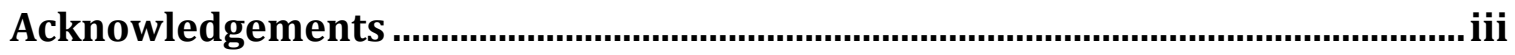

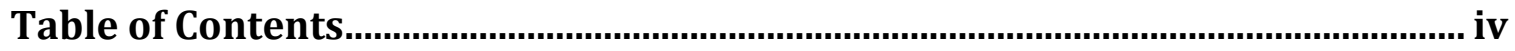

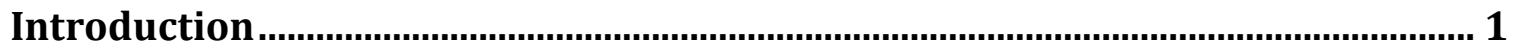

Historiography: Conflicts, Complexities, and Omissions ……............................................... 3

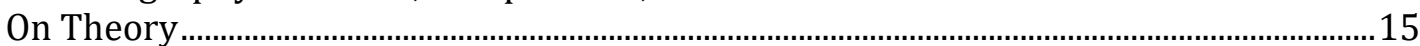

Marguerite Durand and La Fronde: Journalism and Taking Up Space ................................18

Natalie Barney, Renée Vivien, and Sappho: Remaking Tradition............................................23

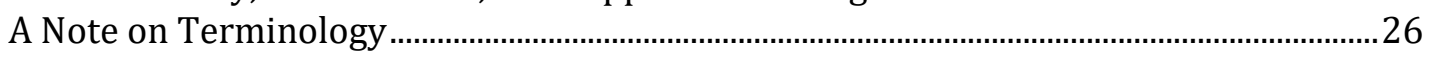

By Women, For Women: La Fronde and Taking Up Space, 1897-1903 ...............28

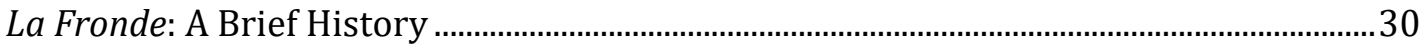

Economic Diversity: Multiple Classes, Multiple Perspectives................................................35

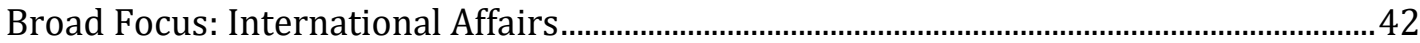

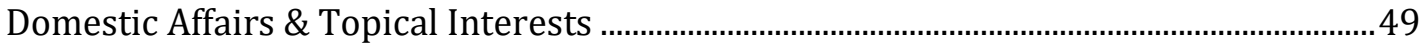

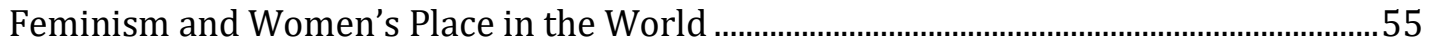

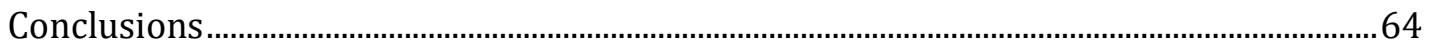

Natalie Clifford Barney, Renée Vivien, and Sappho: Tradition as Resistance,

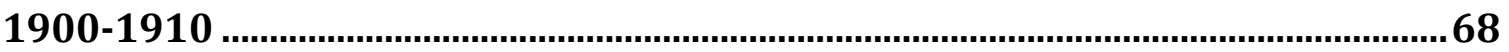

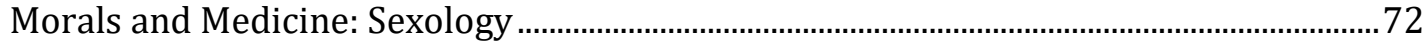

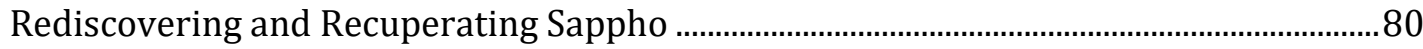

Entangled Meanings: Sappho and Lesbos .............................................................................. 86

Paris: Re-Creating Sappho's Tradition ...................................................................................... 92

Conclusions: Rethinking Tradition as Resistance..................................................................98

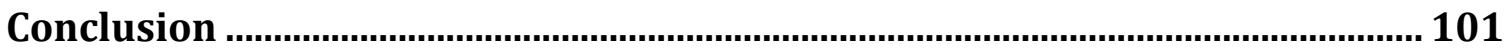

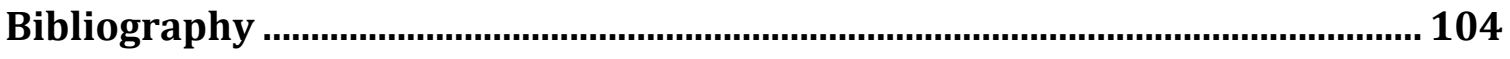




\section{Introduction}

“Paris is a woman's town," wrote Henry van Dyke in his poem America for Me. ${ }^{1}$ Though Van Dyke likely referred to Paris's romantic connotations ${ }^{2}$ by the fin-de-siècle era, Paris had indeed become a woman's town in a very different way. In fin-de-siècle Paris, specifically the last decade of the nineteenth century and first decade of the twentieth, women became more politically, legally, and socially active and influential. While some saw Paris's fin-de-siècle as typifying moral and cultural degeneration, yet for others it represented hope for change. ${ }^{3}$ This was certainly true for the women who approached the fin-de-siècle era with new ideas, and optimism for the twentieth century and the changes it would bring. For women who felt restricted by nineteenth-century morality, the fin-de-siècle brought opportunities to alter the very landscape of their existence.

This thesis examines how women living in fin-de-siècle Paris used their writing to resist restrictive and regulatory norms and discourses that sought to police their gender and sexuality. It includes two case studies. The first examines Marguerite Durand's newspaper La Fronde and the challenges it posed to male predominance in journalism through its content, which included social, legal, political, and economic commentary. The second explores the writing of Natalie Clifford Barney and Renée Vivien, ${ }^{4}$ two Anglo-American lesbian women living in Paris, and their remaking of Sapphic tradition

${ }^{1}$ Henry Van Dyke. "America for Me” in The Poems of Henry Van Dyke (New York: Charles Scribner's Sons, 1911), 167.

2 Ibid. The line concludes "[...] with flowers in her hair."

3 Talia Schaffer, Literature and Culture at the Fin de Siècle (New York, NY: Longman, 2007), 3.

${ }^{4}$ Born Pauline Mary Tarn. 
in resistance to sexological discourses that posited their lesbianism as abnormal and isolating. The thesis is based on a careful analysis of a substantial body of journalistic work from La Fronde and plays and poems by Barney and Vivien, all of which was written in Paris between 1897 and 1910.

Though La Fronde and Barney and Vivien's works did not directly engage with one another, together they constitute a cross-disciplinary body of women's writing that provides insight into the ways in which women resisted normative discourses seeking to police their place in society. These modes of resistance were diverse, taking various forms depending on the women's goals. For example, La Fronde's focus was much more political than that of Barney and Vivien's work. Durand and the frondeuses - contributors to La Fronde - sought to rectify social, legal, and political ills that they perceived in finde-siècle France, while Barney and Vivien creatively resisted sexology's discursive authority. Despite the different forms of restriction and regulation that each group of women encountered, they both represented important instances of resistance in fin-desiècle Paris. To date, however, they have not been put in conversation with one another as examples of women's writing as resistance.

This thesis brings together two lines of historical inquiry that have usually been studied in isolation: histories of feminism, and histories of sexuality. Though these histories have points of overlap, they have usually been taken separately. Despite the wealth of scholarly writing about La Fronde and Barney respectively, there has been relatively little effort to put these two groups of women, their writing, and their modes of resistance into conversation with one another. This thesis brings them together in order 
to suggest new lines of historiographical inquiry about women using writing as resistance.

\section{Historiography: Conflicts, Complexities, and Omissions}

Because La Fronde and Barney and Vivien have yet to be brought together in scholarship, this thesis draws on scholarship from two very different historiographical threads. The first explores feminism, journalism, and the New Woman in fin-de-siècle Paris. The second thread examines the lives of Barney and Vivien, lesbianism, antiquity, and sexology in Paris in the early years of the twentieth century. Although Barney, Vivien, and Durand's frondeuses lived and wrote at the same time and in the same city, studies of them run parallel and rarely intersect. This thesis demonstrates the benefits of a more inclusive approach to studying these women and their writing.

In Disruptive Acts: The New Woman in Fin-de-Siècle France, Mary Louise Roberts examined the New Woman and what Roberts referred to as the "problem of cultural change" that New Women posed. ${ }^{5}$ For Roberts, New Women were both the theatrical and literary trope that had been taken up by Parisian print culture and thought to be an Anglo-American import, and also a group of women who resisted being restricted to the social roles of wife and mother. ${ }^{6}$ Rather than approaching the New Woman as a sociological phenomenon or a cultural stereotype, Roberts examined New Women as a way of analyzing how women began resisting their so-called "domestic destiny."7

${ }^{5}$ Mary Louise Roberts, Disruptive Acts: The New Woman in Fin-de-Siècle France (Chicago \& London: University of Chicago Press, 2002), 8.

${ }^{6}$ Ibid.

${ }^{7}$ Ibid. 
This destiny, which relegated women to the roles of wife and mother, was questioned during the fin-de-siècle era in Paris, and Roberts's analysis of New Women as those who "acted up" and revealed the constructed nature of domesticity elucidated the relationship between New Women and the interrogation of women's domestic destiny. ${ }^{8}$ In Disruptive Acts, Roberts presented case studies of these New Women, including journalists, actresses, and doctors, in order to analyze the ways in which their disruptive acts questioned assumptions about women's role in society.

In her chapters "The New Woman" and "Acting Up," Roberts analyzes the life and work of Marguerite Durand, an actress and avowed feminist who founded $L a$ Fronde. Roberts's analysis of Durand is based partially on her work as a feminist and editor of La Fronde and partially on more anecdotal and personal accounts of Durand's life as a feminist. Roberts notes that, despite being openly and vocally feminist, Durand refused to refer to La Fronde as a feminist paper. ${ }^{9}$ This fact is a critical part of Roberts's analysis of La Fronde's place in Parisian society. Because La Fronde was neither explicitly feminist nor explicitly feminine - two categories into which women's journalism was often categorized - it was not culturally legible through lenses of gendered assumptions. ${ }^{10}$ For Roberts, this complexity is what makes La Fronde one of Durand's disruptive acts.

Not all scholarship agrees that La Fronde was neither explicitly feminist nor feminine. In her book Gender, Citizenship and Newspapers: Historical and Transnational Perspectives, Jane Chapman examined La Fronde and concluded that it

8 Ibid., 49.

${ }^{9}$ Ibid., 9.

${ }^{10}$ Ibid., 76. 
was in fact both explicitly feminist and explicitly feminine. ${ }^{11}$ For Chapman, La Fronde "provided a bridge" between feminism and "feminized" journalism. ${ }^{12}$ Chapman described "feminized dailies" as newspapers run by men that were consciously crafted for women; these newspapers included serialized novels, advertisements, true crime stories, and very little political commentary. Chapman argues that, by combining aspects of conservatively feminized daily newspapers with political, legal, and social debates by and for women, La Fronde demonstrated an alternative way of catering to women in fin-desiècle Paris. ${ }^{13}$ Chapman's analysis contrasts La Fronde's relatively successful six-year publishing peak with The Daily Mirror's one-year stint as a feminized daily. ${ }^{14}$ What set La Fronde and The Daily Mirror apart, she argues, was that La Fronde broke new ground by combining serious debates with aspects of feminized dailies, whereas The Daily Mirror remained "a conservative feminization of The Daily Mail."15 Chapman's analysis implies that La Fronde's success was due, at least in part, to its engagement with feminism and more serious debates.

Maggie Allison also characterized La Fronde as a self-consciously feminist paper. In her entry "Marguerite Durand and La Fronde: Voicing Women of the Belle Epoque," Allison argued that La Fronde was an "overtly feminist publication."16 Allison's analysis

\footnotetext{
11 Jane Chapman, Gender, Citizenship and Newspapers: Historical and Transnational Perspectives (Basingstoke, UK: Palgrave Macmillan, 2013), 63.

12 Ibid.

13 Ibid.

14 Ibid., 63-95. The Daily Mirror exists to this day as a tabloid paper, however from 1903 to 1904 it was conceived as a newspaper for women, and had female journalists (though was not run exclusively by women). When this failed, all its female journalists were fired and it was reconceptualized as something closer to its current standing. 15 Ibid., 80.

16 Maggie Allison, "Marguerite Durand and La Fronde: Voicing Women of the Belle Epoque" in A Belle Époque?: Women in French Society and Culture 1890-1914 ed. Diana Holmes \& Carrie Tarr (New York \& Oxford: Berghahn Books, 2006), 37.
} 
of La Fronde, done in conjunction with Durand's own life, concludes that La Fronde was explicitly founded to further Durand's feminist cause. ${ }^{17}$ Allison's analysis seems often to conflate Durand's feminism with the goals of La Fronde's many contributors, arguing that Sévérine's column "Notes d'une Frondeuse" "spearheaded the feminist content of the paper."18 In fact, this thesis shows that, while Sévérine also subscribed to feminist politics, "Notes d'une Frondeuse" focused for the most part on political, legal, and social issues outside the realm of feminism. ${ }^{19}$ Allison's analysis seems to imply that because many of La Fronde's contributors were feminists, its existence was necessarily explicitly and consciously about furthering their feminist cause. This not only conflates personal politics with professional endeavours, but also ignores the heterogeneity of La Fronde's content.

Although La Fronde ran feminist articles, it also reported on domestic and international affairs outside the realm of feminism, including antisemitism and class conflict. While these issues undoubtedly affected women in fin-de-siècle Paris, $L a$ Fronde's content was not exclusively feminist, nor was it exclusively representative of one point of view. This thesis argues that La Fronde's goal was more complex than simply furthering Durand's feminist cause or representing a singular feminist position. Rather, the paper and its writers invaded the traditionally male sector of journalism, and in doing so resisted social norms that sought to relegate Durand and La Fronde's other contributors to roles as wives or mothers. Therefore, even if La Fronde can be seen as feminist in that it was by and for women and invaded a traditionally male sector, it was

17 Ibid., 39.

18 Ibid., 38.

19 Sévérine, "Notes d'une Frondeuse," La Fronde (Paris) 1897-1903. 
not a publication dedicated exclusively to presenting feminist ideas or furthering a singular feminist cause.

Also in A Belle Époque?: Women in French Society and Culture 1890-1914, Máire Cross examined feminism's role in fin-de-siècle Paris, ${ }^{20}$ in a way that highlights further the complexity of La Fronde's content in relation to Parisian feminist movements of the time. In “1890-1914: A 'Belle Époque’ for Feminism?,” Cross critiqued the simultaneous nostalgia and "deflationary desire" present when regarding fin-de-siècle through the lens of feminism's "post-1968 achievements," 21 and argued that fin-de-siècle Parisian feminist movements provided an important example of feminism's heterogeneity. Cross's analysis of fin-de-siècle feminism focuses on multiple core issues: republicanism, women's desire to participate in public life, class inequality, and religion.

Cross notes that, though the Third Republic's legislation often kept women relegated to social roles on the basis of their gender, "by far the majority of women in feminist organisations willingly accepted republican culture."22 This may have been due to the fact that democracy and republicanism had become conflated in France, and that despite being excluded from the former, women could to a certain extent participate in the latter. ${ }^{23}$ Hence, Cross notes, "women were not considered a threat to political stability" precisely because their political engagement was centred on participating in, rather than dismantling, republicanism. ${ }^{24}$ This argument ties into another aspect of fin-desiècle feminism: women's desire to participate in public life. While for some this

${ }^{20}$ Máire Cross, "1890-1914: A 'Belle Époque' for Feminism?” in A Belle Époque?: Women in French Society and Culture 1890-1914 ed. Diana Holmes \& Carrie Tarr (New York \& Oxord: Berghahn Books, 2006), 23-35.

${ }^{21}$ Ibid., 24.

22 Ibid., 27.

23 Ibid., 26.

${ }^{24}$ Ibid., 27. 
involved radical rejection of patriarchal influence, Cross notes that many women who sought greater political and social emancipation favoured moderate reform and, indeed, rejected the label of 'feminist' entirely. ${ }^{25}$

Cross also examined the influence of class and religious differences on the fin-desiècle feminist and emancipatory movements in Paris. Her analysis argues that it was these differences, rather than who did and did not identify as a feminist, that ideologically split Paris's fin-de-siècle feminist movements. ${ }^{26}$ Feminist movements were divided along class lines especially when working-class women's desires contradicted those of middleclass women. For example, Cross notes that working-class women's suggestion that their employers perform their domestic servants' duties and give them time off once a week "was met with stony refusal."27 This conflict, between middle-class women and workingclass women took precedence over shared struggles as women. ${ }^{28}$ Feminist movements were also divided along religious lines; Cross states that the "clerical-anticlerical debate $[\ldots]$ meant that inevitably a wedge was driven between Catholic and republican feminism." 29

Rather than proving fin-de-siècle feminism's fractiousness, Cross's analysis of Paris's fin-de-siècle feminist movements argues that they were proof that "heterogeneity is a critical feature of feminism." 30 Thus, feminism in fin-de-siècle Paris contained multiple movements, many of which disagreed with one another over goals and tactics. ${ }^{31}$ Taking this into account, it is difficult to categorize La Fronde as a self-consciously

25 Ibid., 31.

26 Ibid., 31-34.

27 Ibid., 33.

28 Ibid.

${ }^{29}$ Ibid., 32.

30 Ibid.

${ }^{31}$ Ibid. 
feminist paper whose singular goal was to promote Durand's feminist cause. Given the goals and tactics of feminist movements in fin-de-siècle Paris, it seems more likely that La Fronde's feminism can be found in its feminist commentary rather than in its very existence.

Around the same time as La Fronde's most important publishing was occurring, Anglo-Americans began relocating to Paris in larger numbers. Shari Benstock historically and critically analyzed the lives and works of expatriate Anglo-American women living on Paris's Left Bank between the late nineteenth and mid-twentieth centuries in Women of the Left Bank. ${ }^{32}$ Benstock's pioneering analysis explored the social, cultural, and geographical contexts in which these women lived and worked, as well as their writing fictional and otherwise - in order to craft a narrative that disrupted then-received knowledge about women's life in early twentieth-century Paris. Benstock's study included an array of women of various political, social, and economic backgrounds. Her first chapter, "Women of the Left Bank," pointed out that while many expatriate men living on the Left Bank were modestly middle class, women living in the same area came from more diverse socio-economic backgrounds. ${ }^{33}$ Benstock noted that generally, "the women of the expatriate community experienced greater financial freedom than the men."34

In Paris, Benstock argued, expatriate women went to Paris to escape lives that were either restrictive or directionless. ${ }^{35}$ Benstock used the example of Gertrude Stein, an American lesbian author and salon host, to illustrate women's attempts to escape by

\footnotetext{
${ }^{32}$ Shari Benstock, Women of the Left Bank (Austin, TX: University of Texas Press, 1986).

33 Ibid., 21.

34 Ibid.

${ }^{35} \underline{\text { Ibid. }}$., 24-25.
} 
moving to Paris. ${ }^{36}$ For Stein, Paris represented the possibility of escape from a directionless life. ${ }^{37}$ In her analysis, Benstock studied the various ways in which women in Paris's Left Bank interacted with their neighbourhood. Benstock also dedicated a chapter to Natalie Clifford Barney, who was another lesbian salon host and author, yet was very different from Stein in the ways she behaved and interacted with other residents of the Left Bank. Whereas Stein wanted a place among the men of Paris's Left Bank and used her salon to achieve that, Benstock highlighted how Natalie Clifford Barney sought to bring others together through her salon more than to promote her own work. ${ }^{38}$

Much attention has been paid to Barney and Vivien's relationship to Sappho and to Paris. Joanne Winning examined Barney and other lesbian women's relationship to Paris in her chapter "The Sapphiest in the City: Lesbian Modernist Paris and Sapphic Modernity" in Sapphic Modernities. ${ }^{39}$ In it, Winning examined the relationship between women such as Sylvia Beach and Natalie Clifford Barney in order to discern a Sapphic map that overlaid the Left Bank neighbourhoods in which lesbian women lived. Winning puts Beach, who ran a publishing house and the bookshop Shakespeare and Company, and Barney, who ran a literary salon, in spatial conversation with one another in order to create a Sapphic map. This map, she argues, elucidated the ways in which Sapphic women ${ }^{40}$ used space "in order to participate in modernity." 41 Drawing on Henri Lefebvre's sociological theorizing of space, Winning posits Beach's bookshop as a "lived

\footnotetext{
36 Ibid., 25.

37 Ibid.

38 Ibid., 27.

39 Joanne Winning, "The Sapphist in the City: Lesbian Modernist Paris and Sapphic Modernity" in Sapphic Modernities: Sexuality, Women and National Culture ed. Laura Doan \& Jane Garrity (Basingstoke, UK: Palgrave Macmillan, 2006), 17-34.

${ }^{40}$ Ibid., 27. Winning's term.

${ }^{41}$ Ibid.
} 
space" within the "social space" mapped by Sapphic women's existence on the Left Bank. ${ }^{42}$

Tama Lea Engelking has examined Barney and Vivien's relationship to Sappho in multiple publications. In her chapter in A 'Belle Epoque'? entitled 'Decadence and the Woman Writer: Renée Vivien's Une femme m'apparut," Engelking analyzes Renée Vivien's relationship to Sappho and the literary tradition of Decadence. ${ }^{43}$ Her analysis places Vivien's interpretation of Sappho within the Decadent tradition, arguing that Vivien was "able to adopt decadence as part of a conscious feminist strategy to redefine the relationship between creativity and sexual identity."44 Engelking analyzed Vivien's semi-autobiographical novel Une femme m'apparut as an appropriation of Decadence's usually misogynistic tropes for Vivien's own purposes. ${ }^{45}$ Engelking notes that while Decadence usually portrayed lesbians as “crazy, violent and destructive," Vivien used Decadent tradition in tandem with her celebration of lesbianism to openly challenge Decadent conventions. ${ }^{46}$ Engelking concludes that Une femme m'apparut constituted an example of Vivien's “woman-centred version of decadence," and warns against conflating her personal life with her creative output. ${ }^{47}$

Interestingly, Engelking's examination of Barney's relationship to Sappho focuses intently on Barney's personal life, specifically her friendship with Pierre Louÿs

\footnotetext{
42 Ibid., 27-30.

43 Tama Lea Engelking, "Decadence and the Woman Writer: Renée Vivien's Une femme m'apparut" in A 'Belle Epoque'?: Women in French Society and Culture 1890-1914 ed. Diana Holmes and Carrie Tarr (New York \& Oxford: Berghahn Books, 2006), 225-237.

44 Ibid., 225.

45 Ibid.

${ }^{46}$ Ibid., 226.

47 Ibid., 236.
} 
and his possible influences on her writing. ${ }^{48}$ In her article "Translating the Lesbian Writer: Pierre Louÿs, Natalie Barney, and 'Girls of the Future Society',' Engelking examined Barney's poetic output, arguing that Barney was looking "for literary models that she could 'stretch' to include a lesbian perspective." 49 Using Barney's poetic collection Quelques potraits-sonnets de femmes as an example, Engelking tied Barney's personal life closely to her creative life. She makes particular note of Barney's friendship and professional relationship with Louÿs - who edited some of her writing - and her relationships with other authors living on the Left Bank, including Ezra Pound, Paul Valéry, and Remy de Gourmont. ${ }^{50}$

Engelking also details the ways in which Barney's references to Sappho in her volume Cinq petits dialogues grecs may have been inspired by, or were in the spirit of, Louÿs's literary hoax Les Chansons de Bilitis. Despite these similarities, Engelking argued, Louÿs and Barney diverged on the subject of community; in Bilitis, Louÿs omitted any sense of lesbian community surrounding Sappho and her followers, whereas Barney's writing consistently tied Sappho and community together. ${ }^{51}$ Engelking concludes that, despite their differences, both Les Chansons de Bilitis and Louÿs's friendship were stepping stones that "Natalie Clifford Barney [...] used to forge her own path toward Lesbos." 52

\footnotetext{
48 Tama Lea Engelking, "Translating the Lesbian Writer: Pierre Louÿs, Natalie Barney, and 'Girls of the Future Society'," South Central Review 22 (2005), 62-77.

${ }^{49}$ Ibid., 67.

50 Ibid., 66. Interestingly, Engelking only lists male "conquests" (her term), and notes that Barney's relationships with women writers can be found through the number of fictional works that feature a fictionalized version of Barney.

51 Ibid., 71.

52 Ibid., 75.
} 
Multiple biographical works discuss Natalie Clifford Barney and Renée Vivien in various ways, and many cover similar major life events. However, some provide more information about Vivien and Barney, or more in-depth historical analysis. The main biographies informing this thesis are by Suzanne Rodriguez and Karla Jay. ${ }^{53}$ These are not the only biographies of Barney, nor are they the most recent. In the 1970s, George Wickes and Jean Chalon both wrote biographies of Barney that detailed her personal life and her romantic exploits. ${ }^{54}$ And in 2005 Diana Souhami published Wild Girls: Paris, Sappho, and Art: The Lives and Loves of Natalie Barney and Romaine Brooks. ${ }^{55}$ Both Wickes's and Chalon's biographies focused almost exclusively on Barney's personal life and her romantic exploits, with Benstock noting that Chalon and Wickes both portray Barney as a female Don Juan. ${ }^{56}$ Souhami's work also followed this pattern, presenting a dual biography of Barney and her lover Romaine Brooks during their relationship in the interwar period. Souhami’s work, however, takes a much more artistic and pseudofictional approach; in it, she interspersed snippets of her own life with her biographies of Barney and Brooks.

Suzanne Rodriguez's biography of Barney, Wild Heart: A Life, provides a comprehensive overview of Barney's upbringing, relationships, and work. Beginning with a genealogy of Barney's family, Rodriguez describes Barney's childhood,

\footnotetext{
${ }^{53}$ Karla Jay, The Amazon and the Page: Natalie Clifford Barney and Renée Vivien (Bloomington, IN: Indiana University Press, 1988); Suzanne Rodriguez, Wild Heart: A Life: Natalie Clifford Barney and the Decadence of Literary Paris (New York, NY: Harper Collins, 2009). 54 Jean Chalon, Portrait of a Seductress (New York, NY: Crown Publishing Group, 1979); George Wickes, The Amazon of Letters: The Life and Loves of Natalie Barney (New York, NY: Putnam Publishing Group, 1976).

55 Diana Souhami, Wild Girls: Paris, Sappho, and Art: The Lives and Loves of Natalie Barney and Romaine Brooks (New York, NY: St Martin's Press, 2005).

${ }^{56}$ Benstock, Women of the Left Bank, 271.
} 
adolescence, and adulthood in great detail. ${ }^{57}$ This biography strays from strict historicity in that Rodriguez frequently speculates on Barney's inner life, and its narrative focuses heavily on Barney's sexual and romantic exploits. Shari Benstock critiques biographers that relegate Barney's lesbianism to the subject of personal gossip, ${ }^{58}$ and Rodriguez's biography is occasionally guilty of this. It does nonetheless provide an in-depth description of Barney's childhood in America, material that many biographies omit.

Although Rodriguez's biography provides valuable insight into both Barney's potential motivations and impact of her personal life on her work, it omits significant analysis of primary sources taken from Barney's life such as her writing or first-hand accounts of her. Indeed, her biography is largely based on secondary sources, mostly earlier biographies. This is problematic, as Rodriguez is forced to speculate about Barney's inner life while discussing what has been detailed in other scholarship.

The literary critic Karla Jay contributed a dual biography of Barney and Vivien, which tied their lives together in a way that moved beyond their romantic relationship with The Amazon and the Page: Natalie Clifford Barney and Renée Vivien. ${ }^{59}$ Instead of restricting herself to discussing Barney and Vivien's relationship or focusing mainly on the tragedy of Vivien's death, Jay also analyzed their literary works and their inspiration. Jay's biography includes a chapter about Sappho that examines her importance to Barney and Vivien, and their worship of Sappho as a goddess. In this chapter, as in the rest of the biography, Jay's argument is rooted in literary, rather than historical, analysis and Jay

57 Suzanne Rodriguez, Wild Heart: A Life.

58 Benstock, Women of the Left Bank, 271.

${ }^{59}$ Karla Jay, The Amazon and the Page: Natalie Clifford Barney and Renée Vivien (Bloomington, IN: Indiana University Press, 1988). 
takes an approach that considers Symbolism and Judeo-Christian influences on Barney and Vivien's engagement with Sappho. ${ }^{60}$

Because Barney and Vivien's biographers are not historians and their studies of Barney and Vivien's lives are grounded in journalistic and/or literary analysis, the biographies, while useful for providing the details of Barney and Vivien's lives and how the women were perceived, are not always strictly historical. This is true as well of much of the scholarship about Vivien and Barney, including that written by Tama Lea Engelking, Joanne Winning, and Tirza True Latimer, who are also not historians. This does not necessarily mean that their analyses of Vivien and Barney are ahistorical, but rather that their analyses are informed by their own scholarly disciplines.

This thesis departs from previous Barney and Vivien scholarship by offering an examination of them that is more situated within the broader discourses and developments of the period. It further brings together parallel scholarly threads on Durand and La Fronde and Barney and Vivien to analyze the two cases in juxtaposition with one another. By bringing these scholarly threads together and by examining two groups of women who lived in Paris at the same time but have yet to be studied in conjunction, this thesis suggests new possibilities for historical inquiry into women, writing, and resistance in fin-de-siècle Paris.

\section{On Theory}

Because this thesis engages with multiple scholarly approaches, its theoretical debts are diverse. This thesis draws on theoretical approaches from a broad range of disciplines, including history, sociology, and philosophy. More broadly, its analysis is

${ }^{60} \underline{\text { Ibid., }}$ 61-80. 
informed by scholarship on the history of gender and sexuality, and how both influence historical inquiry's nature and results.

The first chapter of this thesis is a discussion of how La Fronde's writing allowed women to invade the traditionally male sector of journalism. It is informed by Henri Lefebvre's theoretical work on lived and social space. As Joanne Winning used Lefebvre's concepts of space in order to inform her reading of Sapphic women's lives as a map of social space in Paris's Left Bank, this thesis uses the same concepts in order to understand the ways in which women's invasion of a male sector of business also functioned as an invasion of male social space. Lefebvre's attempt to map modern space - and thus, social space - contained what he called a "perceived-conceived-lived triad."61 Perceived space, as per Lefebvre, is the space as articulated by society; conceived space, the more physical and planned space as conceived by architects and planners; and lived space, which simultaneously incorporates and transcends both perceived and conceived space. ${ }^{62}$ Lefebvre also describes this triad as "spatial practice, representations of space, representational space." 63 This thesis focuses mostly on La Fronde's impact on perceived and lived space. By invading the traditionally male sector of journalism, La Fronde's existence reimagines lived or representational space and thus changes the landscape of perceived space or society's spatial practice by introducing women to a traditionally male-dominated sector.

\footnotetext{
${ }^{61}$ Henri Lefebvre, The Production of Space, trans. Donald Nicholson-Smith (Oxford: Blackwell, 1991), 40.

62 Ibid., 38-40.

${ }^{63}$ Ibid., 40.
} 
This study's analysis of sexuality is informed by the pioneering work of Michel Foucault, especially that of his History of Sexuality: An Introduction. ${ }^{64}$ In the work, Foucault examined the etymological and historical roots of how sexual desires are thought of, discussed, and categorized. Though Foucault's analysis is not necessarily historically accurate, it critiques the notion that repression and discussion are mutually exclusive. Foucault argued in History of Sexuality: An Introduction that sexuality was not repressed in the nineteenth century; instead, new discourses proliferated during this time. More broadly, the book provided an analysis of sexuality based on of Foucault's larger arguments regarding discourse and the production of knowledge.

My analysis draws on the work of E.J. Hobsbawm on tradition, especially in his pioneering volume The Invention of Tradition. ${ }^{65}$ In the introductory essay, Hobsbawm argued that traditions that have claimed to be ancient in fact have been "quite recent in origin and sometimes invented." 66 Hobsbawm further argued that invented traditions

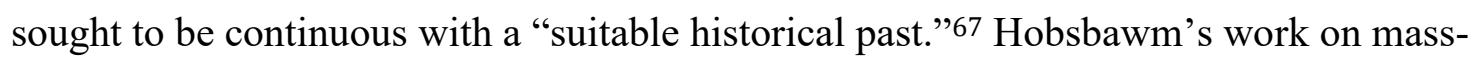
produced traditions in Europe between 1870 and $1914^{68}$ helped me conceptualize how Barney and Vivien remade Sappho's tradition. Hobsbawm analyzed how political and social traditions "invented" at the time were used to reinforce authority or craft identity, particularly with regards to social classes. Specifically, Hobsbawm showed how sport culture became associated with proletarian culture, and argued that sport provided "a

64 Michel Foucault, History of Sexuality: An Introduction (New York, NY: Vintage Books, Random House, 1990. Reprint).

65 Eric Hobsbawm, "Mass-Producing Traditions: Europe, 1870-1914" in The Invention of Tradition, ed. Eric Hobsbawm and Terence Ranger (Cambridge, UK: Cambridge University Press, 1983), 263-308.

66 Eric Hobsbawm, "Introduction: Inventing Traditions" in The Invention of Tradition ed. Eric Hobsbawm and Terence Ranger (Cambridge UK: Cambridge University Press, 1983), 1. ${ }^{67}$ Ibid.

${ }^{68}$ Hobsbawm, "Mass-Producing Traditions," 263-308. 
medium for national identification and a factitious community." ${ }^{69}$ Though Barney and Vivien were not involved in the production of tradition based on sport, nor were they part of proletarian culture, they similarly used their remaking of Sapphic tradition to craft identities and community.

The Invention of Tradition's discussion of Scottish Highland culture and the claim that it had ancient roots despite having only been "invented" in the nineteenth century"0 also helped me to further conceive of how Barney and Vivien linked their version of Sappho's tradition to antiquity. In the essay, Hugh Trevor-Roper details the way in which specifically Highland Scottish culture was developed through a combination of false "histories" and borrowing from neighbouring cultures, ${ }^{71}$ and how it created "new Highland traditions, presented as ancient, original and distinctive" despite its actual roots only being traceable to the late eighteenth century. ${ }^{72}$ Trevor-Roper also argued that Highland culture was useful as a challenge to British authority in Scotland, highlighting the role that British officials' discomfort played in kilts becoming part of Highland tradition..$^{73}$ This discussion helped me further appreciate how Barney and Vivien reworked Sappho's tradition in a similar way.

\section{Marguerite Durand and La Fronde: Journalism and Taking Up Space}

La Fronde was first published on 8 December 1897, and lasted consistently as a standalone publication until December 1903. Its content included opinion pieces,

\footnotetext{
69 Ibid., 300.

${ }^{70}$ Hugh Trevor-Roper, "The Invention of Tradition: The Highland Tradition in Scotland" in The Invention of Tradition ed. Eric Hobsbawm and Terence Ranger (Cambridge UK, Cambridge University Press, 1983), 15-41.

71 Ibid., 18-20.

72 Ibid., 16.

${ }^{73}$ Ibid., 20-21. In this discussion, Trevor-Roper compares British discomfort with Highland kilts to the ban on traditional Irish dress under Henry VIII.
} 
serialized novels, and news covering domestic and international affairs. Within these categories, La Fronde's reporters covered issues affecting various social strata and groups such as strikes and episodes of antisemitism both at home and abroad.

La Fronde's circulation was relatively small; despite selling 200,000 papers per day in its first week, it dropped to 50,000 per day and stayed in that range for the rest of its six-year peak. ${ }^{74}$ La Fronde's diversity of content and its invasion of the male sector of journalism, paired with Durand's refusal to label it a feminist paper, ${ }^{75}$ complicates its resistance to restrictive norms.

Mary Louise Roberts called La Fronde's very existence a "disruptive act" that challenged regulatory norms of womanhood in the fin-de-siècle period. ${ }^{76}$ This is an accurate analysis of its effect. La Fronde's method of disruption came in its invasion of the male sector of journalism and what Roberts called its cultural illegibility. ${ }^{77} \mathrm{By}$ blurring the lines between a feminist paper, a feminine paper, and a professional newspaper in the style of men's papers, Roberts argued that La Fronde rendered itself "culturally illegible in gendered terms." 78 This complication of category also allowed $L a$ Fronde to invade the traditionally male sector of journalism. By creating a newspaper with diverse content, Durand and La Fronde's contributors - called frondeuses - were able to prove themselves able to do what men could, without any men present.

The first chapter of this thesis examines the ways in which La Fronde's content allowed it to invade journalism, a sector traditionally dominated by men, through its economic, political, and feminist reporting. The chapter begins by providing the

\footnotetext{
${ }^{74}$ Chapman, Gender, Citizenship and Newspapers, 87.

75 Roberts, Disruptive Acts, 9.

76 Ibid., 3-9.

77 Ibid., 70.

${ }^{78}$ Roberts, Disruptive Acts, 70.
} 
background to La Fronde's existence as a newspaper. It functioned first as a standalone newspaper for a six-year peak between 1897 and 1903, before becoming a supplement in the newspaper L'Action. ${ }^{79}$ Financial difficulties forced La Fronde's shutdown in 1905, and the paper was published only sporadically between 1905 and 1926. Durand attempted to revitalize La Fronde between 1926 and 1928; however, it was much more overtly political in this incarnation and eventually failed. ${ }^{80}$ This chapter focuses on the six-year peak period of daily publication between 1897 and 1903, when La Fronde was most well-known and most widely circulated. This archive numbers some 1571 issues and covers a variety of major political and social events including the Spanish-American War and the Dreyfus Affair.

The chapter analyzes $L a$ Fronde's reporting on economic issues and the way $L a$ Fronde represented multiple class conflicts and perspectives. Given that class conflict often caused rifts in feminist movements, La Fronde's treatment of economic affairs and class issues is extremely important to any analysis of its content. Though it was founded and run by middle-class women, ${ }^{81}$ La Fronde did not limit its economic and class focus to the bourgeoisie. It reported extensively on working-class issues both in Paris and abroad, including strikes and calls for economic reform. La Fronde also contained a section, "La Finance," which provided financial advice for women managing household finances.

On the same page as "La Finance," La Fronde reported daily on the stock market in "La Bourse.". This suggests that La Fronde took women's financial interests seriously

79 Jean-Louise Debré and Valérie Bochenek, Ces femmes qui ont réveillé la France (Paris: Arthème Fayard, 2013), 374.

80 Ibid.

81 Allison, "Marguerite Durand and La Fronde," 45. 
beyond their capacity as consumers, ${ }^{82}$ and attempted to provide them with information that allowed women to participate financially as best they could. La Fronde's choice of advertisements, which surrounded both "La Bourse" and "La Finance," also challenged typical feminized dailies' practice of surrounding their feminine content with advertisements for beauty, household, and health products. La Fronde associated their feminine ads and advertising space with financial information that women were not expected to take interest in. 83

The chapter's third section examines La Fronde's international focus. La Fronde had a section dedicated to international reports, called "À l'étranger,", which provided brief updates on international affairs. In addition, La Fronde also often made international affairs the focus of standalone articles, which ranged from sensationalist true crime reporting, which was prominent in feminized dailies, ${ }^{84}$ to international feminist issues, to war reporting. It also discussed issues regarding French colonial territories. For example, in 1898, La Fronde published multiple articles regarding antisemitic prejudice and attacks in Algeria. The articles related these outbursts of antisemitism to the issue of foreign non-French presence in the area, and only nominally discussed antisemitism in France in relation to the attacks. Despite this apparent refusal to link antisemitism in France to antisemitism in its colonial territories, La Fronde

82 For a transnational discussion of women and consumerism around the turn of the century, see: Nan Enstad, Ladies of Labor, Girls of Adventure: Working Women, Popular Culture, and Labor Politics at the Turn of the Twentieth Century (New York, NY: Columbia University Press, 1999); Lisa Tiersten, Marianne in the Market: Envisioning Consumer Society in Fin-de-Siècle France (Berkeley, Los Angeles, London: University of California Press, 2001); Tammy C. Whitlock, Crime, Gender and Consumer Culture in Nineteenth-Century England (Abingdon-on-Thames, UK: Routledge, 2005.); Mona L. Russell, Creating the New Egyptian Woman: Consumerism, Education and National Identity, 1863-1922 (Basingstoke, UK: Palgrave Macmillan, 2004). 83 Chapman, Gender, Citizenship and Newspapers, 30. ${ }^{84}$ Ibid., 59. 
unequivocally condemned both these attacks and antisemitic prejudice more generally. This was in keeping with its pro-Dreyfus stance with regards to the Dreyfus Affair.

This affair was paid much attention in La Fronde's domestic reporting, which is the focus of the chapter's fourth section. Though the Dreyfus Affair outlived $L a$ Fronde, ${ }^{85}$ it dominated French society during La Fronde's six-year peak. La Fronde fervently supported Dreyfus and critiqued the French government and military for what the paper perceived as incompetence and antisemitic prejudice. Thus, much of its domestic affairs reporting focused on the Dreyfus Affair's events. This included not only Dreyfus's own trials, but also the trial and temporary exile of the writer Émile Zola, who openly accused the government of antisemitism and incompetence. ${ }^{86}$ One of La Fronde's regular sections, "Notes d'une Frondeuse,"87 featured Sévérine's scathing critiques of how French political and legal systems had operated during the Dreyfus Affair. La Fronde's domestic affairs reporting also covered issues relating to city planning, France's role in military endeavours, suffrage, and education.

In its fifth section, the chapter examines La Fronde's feminist commentary, for which it has become most well known. Rather than presenting a single feminist viewpoint or simply advancing Durand's own feminist cause, La Fronde's feminist commentary was diverse, representing a multitude of opinions. Taken as a whole, La Fronde's feminist commentary provides insight into how its contributors perceived women's place in the world. While some were optimistic about the political and legal changes that allowed for women's further emancipation, others were concerned that women were still

\footnotetext{
${ }^{85}$ Katrin Schultheiss, "The Dreyfus Affair and History," The Journal of the Historical Society 22 (2012), 190. The Dreyfus Affair was not fully resolved until 1906, when Alfred Dreyfus was revealed to have been innocent and was reinstated in the French army. ${ }^{86}$ Ibid.

${ }^{87}$ La Fronde (Paris), 1897-1903. Written by Sévérine, the first French female journalist.
} 
being unfairly marginalized and under-represented in social matters. Thus, La Fronde's feminist commentary was multifaceted and reflected the multitudinous and contradictory nature of Paris's many feminist movements during the fin-de-siècle era.

By combining these diverse viewpoints and approaches in one newspaper, $L a$ Fronde was able to invade the traditionally male sector of journalism, and prove that women were capable of creating a professional, complex newspaper that provided its readers with a wide variety of news and opinions. In other words, it was able to do what male-run newspapers were doing for men, but do it for women, and do it without any men involved.

\section{Natalie Barney, Renée Vivien, and Sappho: Remaking Tradition}

Natalie Clifford Barney (1876-1972) and Renée Vivien (1877-1909), two AngloAmerican lesbian poets who relocated to Paris in the late $19^{\text {th }}$ century, have been variously associated with the Decadent and Modernist movements in Paris. Their relationship lasted nearly a decade, from their 1899 meeting in Paris to their estrangement just before Vivien's death in 1909. Though Barney did not publish prolifically during this period, Vivien did, ${ }^{88}$ and Barney published her collection of plays Actes et Entr'actes soon after Vivien's death. Their literary output in this time period reflects their mutual project of remaking Sappho's tradition in a way that prioritized her same-gender desire and her relationship to Lesbos. Karla Jay has characterized this remaking of tradition as an attempt to deify Sappho and thus worship her as Sappho worshiped Aphrodite in her poetry. ${ }^{89}$ This endeavour, Jay argued, was ultimately a failure, as it took as its touchstone Judeo-Christian values and was in the tradition of Symbolism rather than being a new

88 Jay, The Amazon and the Page, xi.

${ }^{89}$ Ibid. 70-71. 
creation. This made it inherently masculine. ${ }^{90}$ Though Jay's analysis of Barney and Vivien's deification of Sappho includes a discussion of how they reconceptualised her, this discussion is rooted largely in literary analysis rather than in historical context.

This chapter analyzes some of the same writings as Jay, but it takes an historical approach grounded in Hobsbawm's work on the invention of tradition and its use in forming artificially created identities. That is, the chapter grounds Barney and Vivien's remade Sapphic myth historically and frames it within a larger project of making tradition a locus for identity. Instead of being grounded solely in literary analysis, this chapter places Barney and Vivien's remade Sapphic tradition in its historical context and in conversation with other discourses about women's same-gender desires being produced at the time.

This chapter begins by laying out the historical context in which Barney and Vivien wrote, especially with respect to the rise of sexology and a renewed interest in antiquity. These contextual sections discuss the ways in which late nineteenth and early twentieth century conceptions of women's same-gender desire were grounded in sexological studies that posited those desires as abnormal, dangerous, and isolating. Around the same time as sexology's increase in popularity, European society experienced a renewed interest in antiquity. This interest coincided with the late nineteenth century discovery of new Sapphic fragments. ${ }^{91}$ Part of the nineteenth-century engagement with antiquity included women's rising interest in antiquity, a relatively novel phenomenon,

90 Ibid., 80.

91 Engelking, "Translating the Lesbian Writer," 67. 
since women had previously been generally excluded from the education in classics that was mandatory for men. ${ }^{92}$

The chapter next analyzes what Barney and Vivien were writing about Sappho. These sources are poetic and theatrical in nature and, in the absence of contemporary non-fiction autobiographical writing by either Barney or Vivien, provide insight into the ways in which they remade Sappho's tradition. This remaking of Sappho's tradition involved both Barney and Vivien literally rewriting Sappho's death. In Barney's 1910 play Équivoque, which translates roughly to 'ambiguity', two onlookers assume that Sappho had leapt to her death out of love for Phaon. However, Barney's theatrical narrative reveals, after Sappho's death, that she had in fact been in love with Phaon's bride, Timas, and had thrown herself from a cliff out of love for Timas, not Phaon..$^{93}$ This play did not change the main arc of Sappho's death: that she killed herself because the person she loved was married to another. Rather, it changed the details in a way that prioritized Sappho's desire for women.

Vivien, on the other hand, refuted the circumstances of Sappho's death entirely in Sapho. Published in 1901, Sapho compiled a short "biography"94 of Sappho and a collection of Sapphic fragments that Vivien had translated and completed. In Sapho's biographical section, Vivien argued that not only was Sappho not in love with Phaon, but also that Phaon did not exist at all and had been created in order to craft a death legend for Sappho. ${ }^{95}$ Though Vivien did not rewrite Sappho's death, as Barney would in 1910, her refutation of a major component of it similarly remade Sappho's tradition in a way

\footnotetext{
92 Shanyn Fiske, Heretical Hellenism: Women Writers, Ancient Greece, and the Victorian Popular Imagination (Athens, OH: Ohio University Press, 2008), 5.

${ }_{93}$ Natalie Clifford Barney, Équivoque in Actes et Entr'actes (Paris: Sansot et cie., 1910), 49-81

${ }_{94}$ As Vivien called it.

95 Renée Vivien, Sapho (A. Lemerre, 1901), vii-xii.
} 
that excluded desire for men entirely. By erasing Phaon from Sappho's narrative entirely, Vivien refuted Sappho's alleged desire for men and wrote a biography that emphasized Sappho's desire for women.

By remaking Sappho's tradition as one that focused on her explicit desire for women and her association with community on Lesbos, Vivien and Barney were able to resist discourses produced by sexologists that posited lesbianism as corrupt and isolating.

\section{A Note on Terminology}

Throughout this thesis, I variously refer to my main time period as 'turn-of-thecentury', 'fin-de-siècle', and 'Belle Époque'. This time period, in each of its iterations, refers to the decades between 1870 and 1914; when specifically concerning France, it is referred to either as 'fin-de-siècle' or 'Belle Époque', depending on author and subject matter. When concerning England and the European continent more broadly, it is referred to as 'turn-of-the-century' and, for some European countries other than France, 'fin-desiècle'. In order to accurately engage with secondary sources that, collectively, use all three terms interchangeably, I have replicated their respective terminologies.

Additionally, in its second chapter, this thesis uses 'same-gender desire', 'womendesiring women', and lesbianism. This group of descriptions of women's desire for women acknowledges multiple terminologies and sexual desires or identities discussed in the chapter. As well, it is an attempt to discuss some of the desires described by Barney and Vivien without resorting to potentially ahistorical categories of identity. While Barney and Vivien referred to lesbianism to describe themselves, women's desire for women in antiquity cannot necessarily be categorized in such a way, as the terminology did not yet exist. In this thesis, then, I attempt to avoid ahistorically categorizing 
women's desire throughout history. By using multiple descriptions, I also avoid potential confusion while discussing how Barney and Vivien entangled Sappho's and Lesbos's meanings with one another, due to the term 'lesbian's etymological relationship to Lesbos.

I also variously refer to Durand and the frondeuses as well as French activist women more broadly as either feminists or women's rights activists. This is a reflection of their own self-identification as feminists or not. In the case of those who did not identify as feminists, I refer to their actions, rather than retroactively applying the label of feminist to them. 


\section{By Women, For Women: La Fronde and Taking Up Space, 1897-1903}

In Disruptive Acts: The New Woman in Fin-de-Siécle France, Mary Louise Roberts defines "regulatory norms of gender" as "the pervasive set of ideals and practices that attempted to control the terms of male and female in nineteenth-century France." 1 Roberts goes on to describe the ways in which these regulatory norms materialized for women by restricting their social roles to that of wives and mothers, stating that a woman's only expected role beyond that "was decorative - to serve as an ornament for the men in her life."2 These regulatory norms, to use Roberts's term, functioned to restrict women from the public and professional spheres in both political and cultural ways. Third Republic politics and culture limited women to the domestic sphere. ${ }^{3}$ Roberts argues that while many count the fin-de-siècle New Woman as an example of the 'disintegration' or 'decay' of liberal ideals, "the metaphor of exposure seems more accurate."4 That is, rather than destroying turn-of-the-century liberal ideals of gender, the phenomenon of the New Woman - and, indeed, efforts to broaden women's rights more generally - exposed "this vision of sexual difference [...] for what it was - an ideology." 5

One way in which New Women challenged their so-called domestic destiny was through journalism. On December 8, 1897, the first issue of La Fronde was published. The newspaper, which lasted consistently from 1897 to 1903 and then periodically from

\footnotetext{
${ }^{1}$ Mary Louise Roberts, Disruptive Acts: The New Woman in Fin-de-Siècle France (Chicago \& London: The University of Chicago Press, 2002), 3.

2 Ibid.

3 Ibid., 4. Roberts describes this restriction as "liberal" rather than "republican", stating that while the latter suggests a solely political motivation, the former refers more broadly to cultural restrictions and regulations (that were writ politically in the Third Republic's political exclusion of women).

${ }^{4}$ Ibid.

${ }^{5}$ Ibid.
} 
1903 to 1928, was best known for its exclusively female writing and editorial staff. Beginning with its first issue and continuing throughout its major publication period, the paper announced on its front page that it was “dirigé, administré, rédigé, composé par des femmes." ${ }^{\prime 6}$ An eclectic paper, La Fronde covered social, political, and religious news from France and around the world, providing its readers with information on political and social issues from outside France, as well as with feminist news and commentary.

With their newspaper, Durand and her frondeuses invaded, as it were, the 'male' sector of journalism; their project was to create news for and by women, and do so in a space dominated by men. In this way, they resisted stereotypes and expectations that limited them to roles only as wives and/or mothers. ${ }^{7}$ They attempted, Jane Chapman argues in Gender, Citizenship and Newspapers, to bridge a gap between conservatively "feminized" dailies run by men - which included serialized novels and consumer advertisements - and sober political and social commentary for women that included a significant amount of feminist debate. ${ }^{8}$ In this way, by 'invading' male industries and challenging men on their own terms and with their own women-run content, Durand and La Fronde resisted gendered restrictions and regulations in an active and invasive way.

While Marguerite Durand was openly feminist, as were most of La Fronde's contributors, the publication itself did not define itself as explicitly feminist, and Durand resisted labelling it as such initially. ${ }^{9}$ This seems less due to negative connotations

\footnotetext{
${ }^{6}$ La Fronde (Paris) 8 December 1897: 1. Gallica, Bibliothèque Nationale de France.

${ }^{7}$ Roberts. Disruptive Acts, 3.

8 Jane Chapman. Gender, Citizenship and Newspapers: Historical and Transnational Perspectives (Basingstoke, UK: Palgrave Macmillan, 2013), 63.

${ }_{9}^{9}$ Roberts, Disruptive Acts, 9.
} 
associated with feminism at the time - such as that feminists were mannish or aggressive ${ }^{10}$ - and more to do with La Fronde's project as a whole.

La Fronde's intent was not necessarily to report exclusively on feminism, nor was it limited to 'feminine' pieces that men deemed appropriate for women readers. ${ }^{11}$ Indeed, it did not even limit itself to one particular aspect of Paris's feminist community. Rather, its project was to create a newspaper by women, for women, which represented the multiplicity of opinions and political stances of France's female population. La Fronde existed as a female invasion of a profession traditionally controlled by men, and of a social space that men predominantly occupied and controlled. La Fronde functioned in a more complex way than as an explicitly feminist publication ${ }^{12}$ (or one that presented one aspect of Paris's feminist community). Its content included class commentary, reporting on both international and domestic affairs (whether they applied directly to women's issues or not) and multiple, occasionally conflicting, feminist commentaries on domestic and international issues.

\section{La Fronde: A Brief History}

From 1897 to 1903, La Fronde functioned as a standalone publication, issued daily regardless of Christian or French secular holidays. ${ }^{13}$ During this time, La Fronde reported on a variety of topics, including domestic and international affairs, political and social goings-on, and feminist concerns. The paper also included topical essays and

\footnotetext{
10 Ibid., 23.

11 Chapman, Gender, Citizenship and Newspapers, 63. Chapman notes that male editors felt as though newspapers without feminine content were considered "dangerous" for women to read. 12 Maggie Allison, "Margeurite Durand and La Fronde: Voicing Women of the Belle Epoque" in A 'Belle Epoque'?: Women in French Society and Culture 1890-1914 ed. Diana Holmes \& Carrie Tarr (New York \& Oxford: Berghahn Books: 2006), 37-50.

13 Jean-Louise Debré and Valérie Bochenek, Ces femmes qui ont réveillé la France (Paris: Arthème Fayard, 2013), 374.
} 
serialized novels, as well as occasional issues dedicated to reporting on major Parisian events such as Bastille Day celebrations or the Dreyfus Affair. From 1903 to 1905, the paper became a supplement in another publication, L'Action, before financial difficulties forced La Fronde's complete shutdown in 1905. ${ }^{14}$ After 1905, La Fronde made some attempts to begin anew. For about a month in 1914, it was published sporadically; however, its readership was smaller and less interested, as focus in Paris had shifted to the outbreak of World War One. ${ }^{15}$ Between 1926 and 1928, Durand attempted once more to bring La Fronde back to Paris. This too failed, due both to social and political changes and financial troubles. Durand had also by this time veered toward socialist republicanism and eventually to communism, and La Fronde's content followed this shift rather than focusing on feminism. ${ }^{16}$

Thus, the bulk of La Fronde's journalistic work was at the turn of the century, during its years as a daily standalone publication. This archive is significant; from December 8, 1897 to December 31, 1903, it numbers some 1571 issues. Though there are some changes to layout and content, much remains the same throughout its six peak years. Each issue contained several recurring sections, including those dedicated to listing local events such as exhibits or museum tours, international news, brief news snippets from Paris and around Europe, and rumours about political and social goings-on. Each issue also contained four calendars for each date of publication: Republican, Protestant, Orthodox, and Hebrew. ${ }^{17}$

\footnotetext{
14 Ibid.

15 Ibid.

16 Ibid.

${ }_{17}$ La Fronde (Paris) 8 December 1897 - 31 December 1903. Gallica, Bibliothèque Nationale de France.
} 
During La Fronde's six-year peak its front page included one or two major stories, which usually took the form of social or political commentary. Also on the front page was the "Fait Divers" section, which contained brief reports on social and political affairs of the day or week, and the "Aujourd'hui" section, which listed daily events around Paris. Sévérine's column, "Notes d'une frondeuse," also occupied the front page, situated between its two major stories. In later years, the front page included a gossip section, titled "Le potinière." The topical section "La tribune," wherein an author tackled a subject of her choosing, and which changed every three days, generally occupied the second page except in cases where La Fronde's front-page story occupied multiple pages.

For much of the paper's existence, its second page housed the section titled "'À l'étranger,", which contained brief news pieces on international events. Though $\mathrm{La}$ Fronde's international scope expanded gradually throughout its run, "À l'étranger" remained a fixture of the paper until 1903. ${ }^{18}$ In addition to "La tribune" and "À l'étranger," La Fronde's second page also contained reports on current events - such as the Dreyfus Affair or, for a time, the Spanish-American War - which combined reporting with opinion pieces.

This chapter discusses the ways in which La Fronde's project, to create news for and by women, in a space dominated by men, was put into practice through its content. The space La Fronde and its contributors invaded and occupied, in this case, refers to social space created by men's dominance in the sector of journalism. Because journalism was a profession that was necessarily within the public sphere, women were often

${ }^{18}$ La Fronde (Paris), December 1897 - January 1903. 
excluded due to restrictive norms that relegated them to the private world of domestic life. ${ }^{19}$

La Fronde cast a wide net with its content, both geographically and intellectually; the paper included a variety of social views and reported on news from around the world. The paper covered topics relating to professional and working-class women and international news, and also contained multiple topical sections that pertained to feminism or the status of women. These topics and sections not only rendered it "culturally illegible in gendered terms," 20 as they were not all exclusively 'feminine' or feminist, but also allowed La Fronde to bring diverse information to its readership, and function as an equal to its male-run contemporaries on an informative level.

Jane Chapman argues in Gender, Citizenship and Newspapers: Historical and Transnational Perspectives that La Fronde functioned as a bridge between "serious debates about and by women on the one hand, and on the other hand, conservative feminization of the most popular dailies." ${ }^{21}$ By juxtaposing feminist commentary with features of "feminized" dailies that were edited by men, La Fronde created a bridge between Paris's sober, politically minded women, and its women who were more interested in the "trivial" 22 aspects of feminized dailies, and also transcended categories of feminized or feminist. Its focus seems largely to have been on the "serious debates" 23 surrounding feminism, news that affected women of multiple classes, social issues, and international affairs rather than the trivia Chapman describes in what she characterizes as

\footnotetext{
19 Roberts, Disruptive Acts, 4.

${ }^{20}$ Roberts, Disruptive Acts, 76.

21 Jane Chapman, Gender, citizenship and newspapers, 63.

22 Ibid., 80.

${ }^{23}$ Ibid., 63.
} 
‘feminized' dailies such as Britain's The Daily Mirror. ${ }^{24}$ This economic, social, and political focus was similar to that of La Fronde's male-run contemporaries, and while The Daily Mirror included serialized novels, a feature of journalism's "feminization," its main focus seems not to have been to provide women's news. La Fronde's aim, on the other hand, seems to have been to provide women with the same news as male-run newspapers, with the addition of social commentary, usually from a feminist perspective.

Roberts notes that journalism provided a resource for women outside of the nineteenth-century bourgeois liberal culture that restricted their access to politics and the public sphere. ${ }^{25}$ She further points out that journalism reached its peak in the fin-desiècle era, but that it was seen as the "culturally degraded offspring of Haussmannized Paris." ${ }^{26}$ Chapman echoes this, stating that conservatives and intellectual elites were concerned about the feminization of French culture and literature through new journalistic styles and interests. ${ }^{27}$ Durand and some of La Fronde's contributors already had journalistic experience, as it was considered a job that required little professional training, and their occasional presence in male-run journals such as Le Figaro ${ }^{28}$ and $L a$ Libre Parole ${ }^{29}$ suggests that they already were attempting to take up traditionally male spaces, even if it may have been at the expense of their own personal politics. What $L a$ Fronde provided was a way for female journalists to occupy a male sector and thus a male social space, visibly and openly through its declaration of all-female staff, and to do

\footnotetext{
${ }^{24}$ Ibid., 80.

25 Roberts, Disruptive Acts, 10.

26 Ibid., 13.

${ }^{27}$ Chapman, Gender, Citizenship and Newspapers, 68.

${ }^{28}$ Ibid., 81.

29 Roberts, Disruptive Acts, 145.
} 
so without compromising their political or social views in order to maintain a job under a male editor. ${ }^{30}$

In the face of gendered stereotypes and cultural expectations, Durand and her frondeuses used La Fronde not only to enter into the traditionally male sector of journalism but also to resist contemporary obligations of traditional womanhood by proving that they could do a masculine job, without any male assistance. With $L a$ Fronde, Durand and her employees met and challenged men on their own grounds; they reported on news that could not be seen as typically "feminine" or explicitly feminist and were paid the same wages as men.31 Rather than attempting to carve out their own space, Durand and her frondeuses invaded male space and debates and made them their own. The women of La Fronde resisted economic, political, and social forces that would limit them by visibly and vocally taking up space in a sector traditionally viewed as 'male' in a way that both appropriated so-called professional guidelines for their work and also emphasized that women were capable of doing what men could do, without any men.

\section{Economic Diversity: Multiple Classes, Multiple Perspectives}

Though La Fronde was written, edited, typeset, and published by mostly middleclass women, its focus was not limited to one socio-economic class. ${ }^{32}$ Each issue of $L a$ Fronde had a section dedicated to reporting on the stock market, and while it was not a news story as such, "La Bourse", as it was called, occupied the same page as "La Finance," which offered updates and advice regarding France's financial status. While "La Finance" provided financial advice in the realm of household financial

\footnotetext{
30 And without the potential risk of facing male editors' romantic advances.

${ }^{31}$ Chapman, Gender, Citizenship and Newspapers, 81.

32 Maggie Allison, "Marguerite Durand and La Fronde," 45. Allison notes that despite her own middle-class background, Durand was a strong supporter of trade unions and women's place in them.
} 
management, ${ }^{33}$ such as how to budget or invest, "La Bourse" simply offered daily updates on the stock market. ${ }^{34}$ Notably, though La Fronde underwent fairly constant changes in layout through its six-year peak, both "La Finance" and "La Bourse" remained regular features from its inception until 1903. In the pages of La Fronde, women's financial means were taken seriously, as was their place as consumers. The advertisements surrounding "La Finance" and "La Bourse" on La Fronde's fourth page attempted to sell everything from quinine pills to toothpaste. It seems intentional that the bulk of the paper's advertising was placed among financial updates, with the apparent assumption being that women interested in Paris's financial state or the stock market would likely also have the means to purchase the sundry items advertised.

Broader awareness of Paris's multiple socio-economic classes of women can be found in La Fronde's news stories. Indeed, many of the paper's reports regarding women's issues in Paris take on an element of class awareness, either directly or indirectly. As La Fronde approached its end as a standalone publication in 1903, its class commentary became more and more pronounced; when re-published in 1926, much of its overall commentary was focused on class relationships and struggles in France and elsewhere. For the sake of consistency, and to avoid applying Durand's postwar politics to La Fronde's prewar publications, this analysis will focus only on class analyses that appeared during La Fronde's six-year peak, 1897-1903.

In La Fronde's narrative and layout, women were taken seriously as men's intellectual equals, and as capable of controlling and considering their economic status. Despite the fact that women did not work in finance and were relegated to the role of

33 "La Finance," La Fronde (Paris), 1897-1903.

34 “La Bourse," La Fronde (Paris), 1897-1903. 
managers of household finances, La Fronde still included sections not generally thought to be of interest or relevance to women's domestic financial management. On its final page, the sections "La Finance" and "La Bourse" provided La Fronde's readers with financial updates and advice based on current French economic shifts. That women were given information regarding stocks seems at odds with Chapman's argument that women were not expected to find interest in the "interminably long broadsheet details of shipping, shares, financial ventures, legislative debates and court proceedings" 35 found in newspapers run by and for men. This was part of La Fronde's resistance to assumptions about women's interests made by male editors. La Fronde's inclusion of such information - particularly its financial reports - fits neither with Chapman's analysis of "feminization" 36 of dailies, nor with the "serious debates" 37 that she argues were coupled with it in La Fronde.

Rather, "La Bourse" and "La Finance" stand outside the two halves of La Fronde, perhaps in an attempt to replicate the content of newspapers run by and published for men that women were not expected to find interesting. Though women were not generally assumed (by male editors) to be interested in such things as the stock market, ${ }^{38}$ La Fronde dedicated half of its final page to the matter. In addition, its advertising choices seem to resist typical practices of feminization. Rather than surrounding its feuilletons (serialized novels) with advertisements that might appeal to women, $L a$ Fronde's advertising space is mostly also on its final page. These advertisements were generally feminine in nature, ranging from personal hygiene products such as toothpaste,

\footnotetext{
35 Chapman, Gender, Citizenship and Newspapers, 30.

36 Ibid., 63.

37 Ibid.

${ }^{38}$ Ibid., 30.
} 
soap, and perfume to diet pills and weight loss programs. Chapman states that in feminized dailies such as Le Petit Journal such advertisements would surround the specifically feminine content; 39 however La Fronde's editors chose to juxtapose them with often "unfeminine" financial reporting.

“Chronique Féministe," during its time as a regular column, also frequently could be found on La Fronde's final page, along with theatre news and information about events in Paris and around France. Articles related to domesticity, such as the regular column "Le Home," also graced La Fronde's fourth page. While some have read this juxtaposition of domestic and financial information as incongruous, ${ }^{40}$ it seems instead to be an intentional combining of domestic and financial articles. This juxtaposition further highlights the diversity of La Fronde's readership and ties domesticity and financial awareness together in an intentional way, recognizing the housewife's potential for financial intelligence.

Standalone articles also commented on economic issues in France and abroad. Marie-Louise Néron's article "Courtières ${ }^{41}$ et Tailleurs pour Dames" discussed the strike of tailors and seamstresses employed in workshops. ${ }^{42}$ Néron's article describes how the strike unfolded, stating that while it was not yet a general strike, many women workers were striking in solidarity with tailors. Néron notes that the strike was extremely popular, and that La Fronde's donations to strikers were being funded daily by workers providing them with a modest "mais bien touchante obole". ${ }^{43}$ Néron then critiques wealthier

\footnotetext{
${ }^{39}$ Chapman, Gender, Citizenship and Newspapers, 36.

40 Allison, "Marguerite Durand and La Fronde", 40.

41 "Courtière" seems to be a misspelling of "couturier" - a clothes designer - rather than the feminine of "courtier" (an insurance broker).

${ }^{42}$ Marie-Louise Néron, “Tailleurs pour les dames,” La Fronde (Paris), 19 February 1901, 1-2.

43 Ibid., 2.
} 
women who refused to support the strike, stating "tant pis si elle ne profitent point des avantages obtenus,"44 and pointing out that they still had time to confront "les riches industriels qui vivent de leur travail." 45

Néron's commentary suggests that class solidarity was important in turn of the century Paris, to the point of occasionally subsuming women's solidarity based on gender. Both male and female workers supported the seamstresses' strike; however, some wealthier women did not support working-class women in striking. Néron's critique of unsupportive women was not on the basis of their gender, but rather along class lines. ${ }^{46}$ This class divide amongst women was not new; however, La Fronde's report highlights the lack of cross-class solidarity among women and also the fact that there was a diverse range of approaches to women's issues in Paris at the time. Women's issues were not always necessarily issues of feminism, nor did they affect all Parisian women equally.

In “1890-1914: A 'Belle Epoque’ for Feminism?,” Máire Cross notes that class distinctions between women, even in feminist circles, "frequently took precedence over their shared subordination as a sex. ${ }^{\prime 7}$ Class differences prevented bourgeois women from finding solidarity with working class women more often than not, and this manifested itself through middle class feminists' inaction in strikes and conflicts in feminist congresses. Rather than replicating these divides by ignoring working-class women's issues, Néron and the editors of La Fronde report class disparities in articles about working-class women and strikes. Though La Fronde's contributors and editors,

\footnotetext{
${ }^{44}$ Ibid.

45 Ibid.

46 Ibid.

47 Máire Cross, “1890-1914: A 'Belle Epoque' for Feminism?” in A 'Belle Epoque'?: Women in French Society and Culture 1890-1914 ed. Diana Holmes and Carrie Tarr (New york \& Oxford: Berghahn Books, 2006), 33.
} 
including Durand herself, were middle-class women, they challenged class divides in Parisian feminist communities, and many articles argued for gender-based solidarity that crossed class lines.

In addition to its class commentary with regard to striking workers, La Fronde also reported from Paris's labour exchanges. In 1901, Marie Bonneval's “À la Bourse du Travail" covered the Labour Committee's public report, which was attended by some 2000 people. ${ }^{48}$ In her report, Bonneval details the Labour Committee's attempts to placate striking labourers and notes that some had "déclaré favorable aux revendications des grévistes." ${ }^{49}$ On June 19 1902, Bonneval also reported the acceptance of workers' demands that a place in labour courts be extended to employees. ${ }^{50}$ These demands note that tribunals ought to be elected and represent both employers and employees so as to better resolve disputes. ${ }^{51}$ The approval of these demands would have been important news for both male and female workers, and Bonneval's report notes that workers "des deux sexes" 52 had arrived to hear the Labour Committee's decision.

La Fronde's contributors and editors were middle-class women, as was their intended audience. This is particularly clear in much of its political and social commentary with regards to women's rights. Many of its explicitly feminist articles focused on suffrage, social equality, and equal education. In its financial sections and reports on working-class women's issues - such as equal pay or working hours $-\mathrm{La}$ Fronde showcased its contributors' and editors' awareness of diverse classes and classrelated issues.

\footnotetext{
48 Marie Bonneval, “À la Bourse du Travail,” La Fronde (Paris), 19 February 1901, 2. ${ }^{49}$ Ibid.

50 Marie Bonneval, “Tribune du Travail," La Fronde (Paris), 19 June 1902, 3.

${ }^{51}$ Ibid.

52 Ibid.
} 
While feminist congresses and Paris's broader feminist community were often split along class lines, ${ }^{53}$ La Fronde, though it was published by and intended for educated middle-class women, inserted itself into broader Parisian debates about class relationships. By reporting on working-class women - and men - La Fronde ensured its place as a professional paper with a variety of social and economic perspectives. It also ensured that its readership was aware of Paris's socio-economic diversity and the issues facing working class women, and men. By bringing broader class awareness to its mostly middle class readership, ${ }^{54}$ La Fronde acknowledged and subsequently worked to bridge class divides in feminist debates.

La Fronde's reports on working-class issues and its inclusion of financial information thought by male editors to be uninteresting to female readers ${ }^{55}$ showcases not only its awareness of its readers' interests and place in Paris but also that it sought to represent multiple socio-economic classes and their respective concerns. It inserted itself into debates concerning fair labour laws, equal wages, and union solidarity, while also providing stock market information and consumerist opportunities for its majority middle-class female audience. In this way, La Fronde took up space in class debates and allowed debates over class to take up space in middle-class women's consciousness. This blending of feminist and women's issues with other social causes was La Fronde's great strength. It functioned not necessarily as a bridge between 'feminized' dailies and feminist affairs but rather between its readership and the world in which they lived: each took up space in the other, thanks to La Fronde's content.

53 Cross, "1890-1914: A 'Belle Epoque' for Feminism?”, 33.

54 Allison, "Marguerite Durand and La Fronde," 42.

55 Chapman, Gender, Citizenship and Newspapers, 30. 


\section{Broad Focus: International Affairs}

La Fronde did not focus exclusively on news from Paris, nor indeed exclusively on France. At its start, the paper's international focus was relegated to its section "À l'étranger"; however, this focus grew rapidly into standalone articles and occasionally full-page coverage of international events such as the Spanish-American War. ${ }^{56}$ This international focus, like its domestic news, was not solely based on feminist happenings around the world. And while it included feminist news and victories from other countries, La Fronde's international news was not limited by whether or not it pertained to feminism. It maintained a significant focus on political and social news and events from around Europe and the world.

In many early editions of La Fronde, international news was confined to "À l'étranger" and mostly covered German and/or English affairs. While this section remained throughout La Fronde's six-year peak, in 1897 through to mid-1898 it was often the only source on international political or social goings-on. Occasionally, sections such as "La tribune" or "Chronique Féministe" would also cover international affairs or events, but until La Fronde's international focus expanded, it was “À l'étranger" that mostly provided international news to the paper's readers. On December 91897 , it reported on Germany's reaction to the Dreyfus affair, German-Chinese relations, and the Pope's commentary on the situation of the Irish. ${ }^{57}$ These reports were predominantly informational and did not contain extra commentary or the author's opinions.

La Fronde also published standalone articles covering international affairs. Its issue for December 10, 1897 included the story of a mysterious death in Sweden, which

${ }^{56}$ La Fronde (Paris), April-August 1898. Gallica, Bibliothèque Nationale de France.

57 Claire de Pratz, “À l'étranger,” La Fronde (Paris), 9 December 1897, 2-3. 
blended crime reporting - already a popular feature of late nineteenth-century journalism ${ }^{58}$ - with international reporting. H.S.'s "Une cause célébre en Suède"59 concerned the Broxvik Drama, wherein the seemingly natural death of a Swedish chamberlain was later dramatically revealed to have been murder. ${ }^{60} \mathrm{In}$ it, H.S. details how the secret fiancée of the victim's son, Mlle de Fœgershold, had convinced the son that his mother had poisoned his father - and the scandalous trial that ensued. ${ }^{61}$

H.S.'s narrative does not take the form of a cut-and-dried courthouse report. It reported not only on the trial's twist, focusing on a letter supposedly from Mlle de Fœgershold that confessed to the murder, but also on an incident wherein de Fœgershold was found to have been attacked the previous night. ${ }^{62}$ The report speculated that it was perhaps de Fœgershold herself who arranged the attack in order to avoid prosecution, and concludes by stating that "la police n'est sur aucun piste. On discute, on se passionne - et on attend." ${ }^{63}$ An 1897 edition of the Chicago Tribune described the drama as "the talk of northern Europe," ${ }^{64}$ and it would seem as though this fascination extended to La Fronde and its readers as well.

Much of La Fronde's international reporting was not nearly as sensationalized as "Une cause célébre en Suède." Indeed, most of its international focus was political and social, focusing on injustices or major political shifts in the international landscape. In addition to standalone articles, regular sections such as "La tribune" and "Chronique

\footnotetext{
58 Chapman, Gender, Citizenship and Newspapers, 59.

${ }^{59}$ H.S., "Une cause célébre en Suède," La Fronde (Paris), 10 December 1897, 3.

60 Ibid.

61 Ibid.

62 Ibid.

${ }^{63} \mathrm{Ibid}$.

64 "Mystery in a Murder," Chicago Tribune [Chicago], 23 December 1897, 2.
} 
Féministe" covered international affairs, usually ${ }^{65}$ in the form of feminist commentary. "La Tribune" began publication at the same time as La Fronde, but did not last beyond 1900, at which point it was removed and sporadically replaced by "Semaine artistique," which commented on new art and art history. ${ }^{66}$

"Chronique Féministe" faced the same fate. By the end of 1899, it too had disappeared, though La Fronde continued to report feminist news and commentary in standalone articles. Both sections, while they lasted, were major sources of commentary on international political and social matters. While many of these issues were from within Europe, there were also contributions that discussed social and political affairs beyond the European sphere; most of these articles concerned themselves with colonial questions and areas with a significant French presence or population. Articles outside regular columns also discussed international political and social issues, particularly with regard to French colonial territories.

One such article, from June 15 1898, responded to the phenomenon of antisemitic prejudice and attacks in Algeria. ${ }^{67}$ Caroline d'Ambre's article, "Conclusion," discusses foreign threats to French Algeria, blaming naturalized Spanish and Maltese citizens of Algeria for the antisemitic prejudice in the area and stating that both groups "détestent les Israélites" based on economic rivalries. ${ }^{68}$ Indeed, d'Ambre pins most of French Algeria's problems on one wealthy Maltese family, accusing them of using their wealth to influence others and even sway elections in the area. D'Ambre's article is concerned with

\footnotetext{
65 In the case of "Chronique féministe," all articles covering international affairs were concerning feminism and women's status.

${ }^{66}$ La Fronde (Paris), 1900-1903.

${ }^{67}$ Caroline d'Ambre, "Conclusion," La Fronde (Paris), 15 June 1898, 3.

${ }^{68}$ Ibid. On the other hand, d'Ambre insists that Italians in the area coexisted peacefully with Jews and are more interested in maintaining their fisheries than involving themselves in social troubles.
} 
foreign influence in Algeria and the ways in which foreign presences threatened social cohesion in French colonial territories, using antisemitic prejudice and attacks as an example. However, it also condemns antisemitism in Algeria more broadly, calling it "une des monstruosités les plus exécrables de notre époque.”69

Though the article hardly acknowledges French nationals' antisemitism, ${ }^{70}$ d'Ambre's strong condemnation of antisemitism in Algeria both fits with La Fronde's broader Dreyfusard politics ${ }^{71}$ and suggests that its contributors and editors concerned themselves with marginalized groups other than women. It also reflects colonial concerns about foreign influence on French Algerian politics when it states that naturalized French Algerians from other countries ought not to be able to vote in Algerian elections until their second or third generation due to the influence they exerted over political and social matters. ${ }^{72}$ D'Ambre in this instance uses antisemitic prejudice and attacks in Algeria as an example of the dangers of foreign presence in French colonial territories. French nationals, in this article's narrative, were entirely uninvolved in Algeria's problem of antisemitism, and in this way, the problem of antisemitism in French colonial territories is appropriated to comment on foreign threats to French colonial interests.

Colonial issues were also discussed in Abda's "Questions coloniales," published on February 15 1898, about French-English relations regarding Madagascar. Its author, like d'Ambre, does not question French colonial power or France's "right"73 to Madagascar. Rather, the article discusses French-English relations with regards to

\footnotetext{
69 Ibid.

${ }^{70}$ Ibid. Though she wrote other articles for La Fronde that condemned antisemitism in France, d'Ambre's narrative only mentions the Dreyfus Affair in passing and she states explicitly that French nationals in Algeria were not responsible in any way for antisemitic prejudice or attacks. ${ }^{71}$ Roberts, Disruptive Acts, 108.

72 Caroline d'Ambre, "Conclusion," 3.

73 Abda, "Questions Coloniales," La Fronde (Paris), 15 February 1898, 3.
} 
colonial territories, in particular the way in which England handled becoming protector of Zanzibar and the threats it could pose to France's possession of Madagascar. Abda outlines the way in which the English treated both indigenous and foreign inhabitants of Zanzibar after it became a British protectorate, contrasting English rule in Zanzibar to French rule of colonial territories. Abda's article refers to France's colonial legislation as "métropolitaine, avec les même guaranties pour les étrangers que sur le territoire continental." 74

On the other hand, Abda states, England imposed legislation that applied both to indigenous and foreign (non-English) occupants of Zanzibar and did not afford other European presences the same rights as they might have on the continent. ${ }^{75}$ Relating the issue back to Madagascar once more, Abda cautions her readers and the French government to not be so afraid of being accused of Anglophobia that they will not speak out against English attempts to do the same in Madagascar as in Zanzibar. ${ }^{76}$ This warning suggests that Abda, like D'Ambre, was concerned with foreign influences in French colonial territories. Abda's concern lies in how French-English tensions might manifest in ways harmful to French citizens living in Madagascar, and positions France's colonial rulership as fairer to foreign inhabitants of colonial territories than that of England to reinforce her argument.

Published on December 12 1897, "Algérie-Colonies” dealt with French colonial interests. Its anonymous author provides brief updates from Algeria, Côte d'Ivoire, and

74 Ibid.

75 Ibid.

${ }^{76} \underline{\text { Ibid. }}$. 
Vietnam ${ }^{77}$. This article, like "Questions Coloniales," engages with "les troubles antisémites d'Oran et de Mostaganem," "78 stating that the issues would be resolved by the imprisonment of those found guilty of the attacks. ${ }^{79}$ From Côte d'Ivoire, the article reports on French relations with Samori Ture, referring to him as "l'irréductible Samory," 80 and detailing how welcoming he had been to two French administrators. Both the section on Algeria and that on Côte d'Ivoire are exclusively informational and do not contain author commentary. On the other hand, the report from Vietnam begins by noting that its content refers to "un événement sans précédent"81: that the emperor of Annam had visited Saïgon to pay homage to the French governor general. ${ }^{82}$

These brief snippets of news relating to colonial affairs suggests that La Fronde's readers, writers, and editors were not only supportive of France's colonial efforts but actively interested in the way such efforts were unfolding. This colonial interest is applied to women in "Harems Tunisiens" and "Lettre du Harem," both of which were published in late 1898. In "Lettre du Harem," published on November 15 1898, Yamina states that there are literate women in Islam and that "nous avons, nous aussi, fondé notre Fronde." 83 Her letter attempts to dismantle French assumptions about the status of women in harems and in Algeria more broadly, particularly with reference to how they relate to men, stating that there are plenty of Muslim and Turkish men who treat women well, and that it would be ridiculous to believe that a religious law was capable

\footnotetext{
77 “Algérie-Colonies," La Fronde (Paris), 12 December 1897, 3. In this article, Vietnam is referred to as 'Indo-Chine'.

78 Ibid.

79 Ibid.

80 Ibid.

81 Ibid.

82 Ibid.

${ }_{83}$ Yamina, "Lettre du Harem," La Fronde (Paris), 15 November 1898, 2.
} 
"d'enlever aux femmes tout pouvoir." 84 Though written in French and finishing by flattering the French author to whom it was addressed, ${ }^{85}$ Yamina's letter nonetheless critiques French assumptions about Muslim women's lives.

In its international reporting, La Fronde included 'professional' reporting found in newspapers run by men that discussed foreign affairs and military developments such as Sino-German relations and the Spanish-American War. La Fronde's inclusion of these articles shows that its contributors and publishers were aware that French women were interested in international affairs, and that matters affecting France - feminist or otherwise - necessarily affected French women. It also included extensive reporting on women's affairs and the status of women internationally, particularly with reference to women in French colonial territories.

This blend of news that both explicitly and implicitly concerned French women showcased not only La Fronde's international perspectives - as it reported multiple points of view regarding war and the French military presence abroad ${ }^{86}$ - but also its awareness that its readership was interested in and affected by news from a broad range of sources. As with its diverse economic commentary, La Fronde's international reporting and discussion reflected contemporary social and political opinions and made available to its readers a diverse array of news stories and perspectives. Once again, through its treatment of international affairs, La Fronde occupied space in broader debates, not just about women's issues, and brought these debates to its female readers.

\footnotetext{
${ }^{84}$ Ibid.

85 Ibid. Yamina's letter is written to M. Hugues Le Roux, who then delivered it to La Fronde. 86 While its reports on France's colonial presence were overwhelmingly pro-colonialism, $L a$ Fronde also published staunchly anti-war articles that critiqued France's military presence abroad. See 'Domestic Affairs' section for discussion of Osmont's critique of French military presence and power.
} 
In so doing, it enabled its female readers to invade and participate in debates that were traditionally seen as exclusively male.

\section{Domestic Affairs \& Topical Interests}

Each issue of La Fronde contained several regular sections; these sections varied in content, but many were dedicated to a single focus or the thoughts of a single contributor. These sections mostly explored domestic affairs issues and many of them concerned themselves with the state of the French government, women's status in France, or other social issues such as war, the Dreyfus Affair, and France's justice system. Both "Aujourd'hui" and Sévérine's regular column "Notes d'une Frondeuse" focused on domestic affairs and events in Paris and around France. As well, "Faits Divers" and "La Tribune" also reported and commented on domestic affairs. As with La Fronde's coverage of international affairs, the content of these reports did not limit itself to feminism or the status of women. In fact, much of La Fronde's domestic commentary concerned itself with the Dreyfus Affair and its implications.

A political scandal that shook France and divided its intellectual communities, the Dreyfus Affair began in 1894 when Captain Alfred Dreyfus was accused of treason relating to espionage for Germany and sentenced to life in prison. ${ }^{87}$ One of the most famous incidents during the Dreyfus Affair was Émile Zola's letter J'accuse, published in 1898 , which led to Zola's trial and temporary exile. ${ }^{88}$ Accusations of antisemitism and corruption in the military and justice systems were already present in La Fronde's commentary on Dreyfus's trial ${ }^{89}$ before Zola published J'accuse, suggesting that there

${ }^{87}$ Roberts, Disruptive Acts, 5.

${ }^{88}$ Karin Schultheiss, "The Dreyfus Affair and History," The Journal of the Historical Society (2012), 190.

${ }^{89}$ Roberts, Disruptive Acts, 107-108. 
was, at least in some circles, speculation about the true nature of the charges against Dreyfus.

Due in part to Zola's letter, Dreyfus was re-tried and convicted once more. Eventually, however, he received and accepted a pardon. ${ }^{90}$ By 1906, it had been revealed that all charges against Dreyfus were baseless and he was reinstated in the army. ${ }^{91}$ While it is difficult to assign one single motive for Dreyfus's mistreatment - poor intelligence analysis and fear of Germany were surely also at work in the initial case - it sparked virulent debates and highlighted an undercurrent of strong antisemitism that already existed in France. La Fronde was openly Dreyfusard ${ }^{92}$ and ran multiple articles covering the events of his trials as well as that of Zola. It also strongly critiqued antisemitism not only in colonial territories but also in France, particularly with regards to how the French government treated Jews.

Published on February 15 1898, Caroline d'Ambre's "Juifs et gouvernements" presented a history of the relationship between the French government and Jews in France dating from the Bourbon Restoration to $1898 .{ }^{93}$ The article concludes, overwhelmingly, that French Jews were and continued to be mistreated by their government; d'Ambre then calls on women to help combat institutional and social antisemitism. Though the article is mostly a historical report on injustices against Jews in France by the French government, its call for women to take action mirrors the advocacy against antisemitism in Algeria ${ }^{94}$ found in La Fronde's international affairs reports. In

\footnotetext{
90 Schultheiss, "The Dreyfus Affair and History," 194.

91 Ibid.

92 Allison, "Marguerite Durand and La Fronde", 42.

93 Caroline d'Ambre, "Juifs et gouvernements," La Fronde (Paris), 15 February 1898, 1.

94 D’Ambre also wrote "Conclusion”, which condemned antisemitism in Algeria, later in 1898.
} 
this article, unlike in her article about antisemitism in Algeria, ${ }^{95} \mathrm{~d}^{\prime}$ Ambre does not shy away from placing responsibility for antisemitism squarely on France's government and population. ${ }^{96}$ This advocacy for other socially and politically marginalized groups strengthens the suggestion that the contributors and publishers of La Fronde were interested in securing equality in French law and society for people other than themselves. Put another way, its call for women to combat antisemitism suggests that d'Ambre, at least, sought solidarity with other socially and politically marginalized groups within France.

La Fronde also contained commentary on France's military and legal systems. In May of 1899, Osmont's article "Pour la Paix" reported on an all-female anti-war protest that took place at Paris's Labour Exchange. Osmont's report takes the position of the protestors, stating that "l'inutilité de la guerre, tous les jours, s'affirme,"97 and questioning whether armed peace would be tenable given "les questions coloniales."98 Osmont employs women's roles as mothers to strengthen her anti-war rhetoric, questioning whether women would be fated to always raise their sons for war and brutality. ${ }^{99}$

Osmont's article is less concerned with the deaths of these sons, however, and more concerned with the "odieuse cruauté"100 committed in war. Indeed, she states that

\footnotetext{
95 D'Ambre, "Conclusion," 15 June 1898, 3. See above for discussion of how d'Ambre discusses antisemitism in Algeria as an issue relating to Algeria's foreign non-French presence and her insistence that French nationals were not involved in antisemitism in Algeria.

${ }^{96}$ D'Ambre, "Juifs et gouvernements," 15 February 1989, 1.

97 Osmont, "Pour la Paix," La Fronde (Paris), 15 May 1899, 1.

98 Ibid.

${ }^{99}$ Ibid.

$100 \underline{\text { Ibid. }}$.
} 
not even death could excuse cruelty committed in places such as Madagascar. ${ }^{101}$

Osmont's anti-war commentary bridged international and domestic affairs by commenting on France's military presence in other countries and on its presence within France. ${ }^{102}$ It also reflects women's voices in the anti-war struggle and the rhetoric they employed; one that focused on maternity, but also on the inherently brutal nature of men when engaged in war. While women could not vote or participate officially in politics in the same way as men, Osmont's article showcases the ways in which women participated politically in an unofficial manner: they used La Fronde to participate in political debates.

These debates, regardless of whether they were contained in front page stories or not, were often on La Fronde's front page in "Notes d'une Frondeuse." "Notes d'une Frondeuse" was Sévérine's regular front-page column in La Fronde, and it commented on various political and social issues, including the Dreyfus Affair and parliamentary affairs. As France's first female reporter, Sévérine occupied the traditionally male sector of journalism in her own right before joining La Fronde, as she contributed to and occasionally co-edited male-run papers. ${ }^{103}$ When she joined La Fronde, Sévérine was already established as a highly opinionated reporter, ${ }^{104}$ having edited Le Cri du peuple and contributed to the antisemitic paper La Libre parole. ${ }^{105}$ By ensuring that she had a daily column in which to comment on domestic affairs - which included social, political, and economic matters - La Fronde was able to cement her place in French journalism in a highly visible way. Though Sévérine's writing included nothing as antisemitic as other

\footnotetext{
101 Ibid.

102 Ibid.

103 Roberts, Disruptive Acts, 5.

104 Ibid., 144-45.

105 Ibid.
} 
contributions to La Libre parole, her presence there remains complicated. It is difficult to know whether her contributions were a case of political alignment or an attempt to further invade a male-run newspaper, taking advantage of Edouard Drumont's love for her. ${ }^{106}$ In her contributions to La Fronde, Sévérine was staunchly Dreyfusard, and dedicated multiple editions of "Notes d'une Frondeuse" to the Dreyfus Affair and to critiquing and mocking anti-Dreyfusards. ${ }^{107}$

Sévérine's articles were generally focused on topics not pertaining to feminism, though she herself was staunchly feminist. Like La Fronde more broadly, the feminism evident in Sévérine's writing seems to have stemmed from the very fact that she was not limited with regards to her topics. ${ }^{108}$ Instead, her commentary on French domestic affairs not only occupied space on La Fronde's front page but also inserted her and the paper into debates that did not necessarily relate directly to women's issues or feminism. This invasion of male spaces was often quite literal; Sévérine frequently reported on trials and parliamentary debates. In order to do this, Roberts states that Sévérine would sometimes go undercover, dressing as a man. ${ }^{109}$ Roberts analyzes this as performing or "playacting." 110 Cross-dressing also functioned as a way for women to invade male spaces.

Sévérine explicitly acknowledged her "intervention féminine"111 of male spaces in a July 1898 edition of 'Notes' titled "Questions logiques." 112 In it, she argues that because she paid her taxes "tout comme un homme," 113 she deserved to be aware of and

\footnotetext{
106 Ibid., 145-46.

107 Sévérine, "Notes d'une Frondeuse", La Fronde (Paris), 1898-1903.

108 At least while she wrote for La Fronde. Roberts, Disruptive Acts, 145-6.

109 Roberts, Disruptive Acts, 13.

110 Ibid., 14.

111 Sévérine, "Notes d'une Frondeuse: Questions logiques," La Fronde (Paris), 16 July 1898. 1.

112 Ibid.

113 Ibid.
} 
comment upon military and political matters. Though the rest of her piece concerned itself with strongly criticizing the French military for its actions during the Dreyfus Affair, her defense of women's invasion of, and intervention in, traditionally male sectors succinctly summarizes La Fronde's project. It is notable that Sévérine's intervention is a feminine intervention rather than a feminist intervention. This also reflected La Fronde's focus of being by and for women, but not exclusively feminist. Her reports, placed as they were on the front page amongst other political and social commentary, also functioned to rally women who did not necessarily identify as feminists around $L a$ Fronde's social causes such as the Dreyfus Affair or its anti-war sentiments.

Though its reporting on domestic affairs concerned itself much more often with women's issues - such as suffrage and education - than some of its other sections, $\mathrm{La}$ Fronde nonetheless maintained a diversity of opinion and topic. Its reports on parliamentary debates and on legal issues were particularly explicit examples of women literally invading men's spaces, often through the use of costume or sheer force of will. ${ }^{114}$ In these cases, frondeuses were often the only women in the room, becoming both a visible and literal invasion of male spaces. As with its economic and international commentary, La Fronde also ensured that its domestic reports 'invaded', as it were, its readers' awareness. Be it through calls for women to support Alfred Dreyfus and his family or through appeals to women's roles as wives and mothers to support its anti-war rhetoric, La Fronde ensured that its readers and traditionally male-dominated sectors and debates were viscerally aware of and engaging with one another.

${ }^{114}$ Chapman, Gender, Citizenship and Newspapers, 81. 


\section{Feminism and Women's Place in the World}

In Disruptive Acts, Roberts summarizes Marguerite Durand's feminism by defining it as "a political enterprise that [...] was advanced by feminine wiles."115 By contrast, Chapman analyzed La Fronde as bridging the gap between what she characterized as "feminine" and "feminist" news with a paper that fit neatly into neither category. ${ }^{116}$ Chapman argues that by including typically feminine features such as serialized novels and highly feminized advertisements alongside feminist commentary, La Fronde created a bridge between feminized publications and Paris's feminist movements. Not all feminist articles in La Fronde necessarily extolled femininity. As well, not all of La Fronde's articles about feminism posited one single point of view; because of this, not all articles agreed with one another. This is not surprising, as feminism in fin-de-siècle Paris was a diverse and often contradictory body of rhetoric and action. Chapman notes that some articles directly conflicted with others, an issue that was "sometimes seen by contemporaries as editorial contradictions rather than as reflections of the diversity of discourse."117

Though La Fronde and the women who wrote, edited, and published it were all inextricably associated with the struggle for women's rights in France, as noted, not all of its content was concerned with feminism in its broad or narrow scopes. Indeed, Roberts states that for some time Durand resisted the label of 'feminist' for La Fronde. ${ }^{118}$ Not only did La Fronde not self-identify as a feminist publication ${ }^{119}$ from the outset but also its content was often self-contradictory. Even sections and articles that did advocate for

\footnotetext{
115 Roberts, Disruptive Acts, 50.

116 Chapman, Gender, Citizenship and Newspapers, 63.

117 Ibid., 195.

118 Roberts, Disruptive Acts, 9.

119 Though its first editions did rely heavily on feminist content to fill its pages.
} 
feminism often disagreed with one another in a way that, as Chapman rightfully notes, displays the multiplicity of social and political stances within the scope of feminism as a movement.

La Fronde published feminist commentary from a range of authors, and thus necessarily published a range of feminist opinions. Included in this range were commentaries on sexual freedom, both positive and negative, as well as commentaries on religious and legal matters. Indeed, in an article extolling the virtues of Christian feminism, La Fronde's editors saw fit to include the statement that while La Fronde was "absoluement catholique"120, it would respect and publish "tous les partis féministes."121 This article, entitled "Le Féminisme Chrétien," advocated for specifically Christian feminism and for the use of God and religion to justify feminist works. ${ }^{122}$ This defense of Catholic feminism reflects religious debates happening both within and outside Parisian feminist communities, and which would eventually affect La Fronde's content, turning it from its "absoluement catholique" 123 stance to one that favoured anticlerical republicanism by $1900 .{ }^{124}$ Generally, however, La Fronde commented on secular social and political matters rather than those deeply concerned with religion.

Political commentary occupied much of La Fronde's reporting space, feminist or otherwise; thus much of its feminist commentary concerned itself with French political developments as well. This commentary often made front-page news, particularly in cases where La Fronde reported a feminist victory. On December 10 1897, the paper

\footnotetext{
120 Whether this pro-Catholic stance was an attempt to align La Fronde with more vocal moderate Catholic feminist organizations or a genuine reflection of the editors' views is unclear in the context of the article.

${ }^{121}$ Marie Maugeret, “Le Féminisme Chrétien,” La Fronde (Paris), 11 December 1897, 1.

122 Ibid.

123 Ibid.

124 Allison, "Marguerite Durand and La Fronde," 42.
} 
reported on one such victory: a change in law that allowed women to serve as witnesses in civil acts regarding birth, marriage, and death, regardless of their marital status. V. Milliard's report lays out the specific changes to the law; its language was changed from specifically masculine-focused to "les deux sexes." 125 While other requirements remained the same, ${ }^{126}$ this simple change in language allowed women greater access to France's legal system. Appropriately, V. Milliard referred to the law change as the "don de joyeux avènement." 127

Published alongside this victorious report was a commentary on women's involvement in planning in Paris that presented significantly less optimistic views. "Les femmes dans les comités d'admission à l'exposition de 1900" functioned in two ways: as a report of women involved in organizing the 1900 Exposition Universelle, and as a commentary on under-representation of women in such committees and events. ${ }^{128} \mathrm{~V}$. Vincent notes that out of a total 4000 committee members, only 33 were women; her report names each woman and the sub-committee in which each was involved. This list, however, is only part of her article's purpose. Its other part questions (it would seem only somewhat rhetorically) why women were so poorly represented within the admissions committee. Vincent notes that in some sub-committees for 'feminine' industries, only one woman was involved; worse still, for certain sub-committees concerned with 'masculine' industries, there were no women at all despite women's place within the industries. She states that "les sociétés féministes sont préoccupées de cette insuffisance de la

\footnotetext{
125 V. Milliard, "Don de joyeux avènement," La Fronde (Paris), 10 December 1897, 1.

${ }^{126} \mathrm{Ibid}$. The law required two witnesses, both French and both at least 21 years of age.

127 Ibid. (Translation: "Gift of joyous accession.")

128 V. Vincent, "Les femmes dans les comités d'admission à l'exposition de 1900," La Fronde (Paris), 10 December 1897, 1.
} 
representation des femmes." 129 This suggests that feminist societies were not only concerned with political and legal reform for women but also with the status of women in French society more generally.

Another article that concerned itself with women's role in Parisian society, and more specifically in city planning, is "Hôpital d'enfants," published on March 10, 1898. In it, Marie-Louise Néron reports on a planned children's hospital situated in the city's $18^{\text {th }}$ arrondissement, with a view of the Montmartre Cemetery. ${ }^{130}$ Néron is distressed by the possibility, and outlines the plan for the hospital, in which its long-term care wing overlooks the necropolis. ${ }^{131}$ She objects to the hospital's location (though not the existence of the hospital) on feminist grounds, stating that it was clear that no women were consulted in the planning or placement of the building. ${ }^{132}$ The implication seems to be that no woman would consider building a children's hospital adjacent to cemetery, as they would recognize the horror this would cause in mothers sending their children to stay at the hospital.

"Hôpital d'enfants" makes its feminist point using rhetoric that posits women as inherently aware of wives' and mothers' concerns. This is not entirely uncommon, as Roberts notes; frondeuse's personal relationship to motherhood "did not prevent [them] from extolling motherhood as women's highest calling." 133 This is also visible in "Grève de mères" which, as noted above, referred to the phenomenon of rich American women refusing to have children as a "sickness." 134 Néron authored this article as well, and while

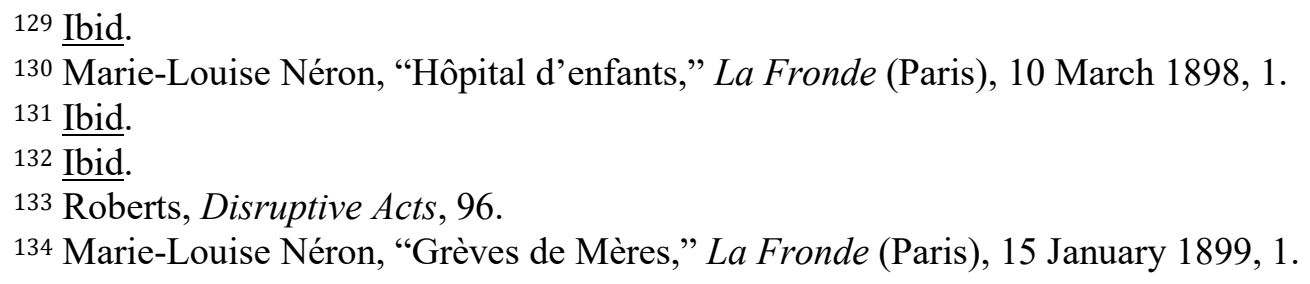


her focus on motherhood may stem from her own personal politics and interests, it may have also reflected the population concerns that plagued France after the Franco-Prussian War. ${ }^{135}$

In its first issue, La Fronde provided its readers with an update of sorts on the work and place of feminism in Paris. In "Féminisme," Maria Pognon laid out the definition of feminism as she sees it: a project requiring communal work by both men and women for women's rights. ${ }^{136}$ Pognon, then-President of the Ligue Française pour la Droit des Femmes, dismantled arguments against women's rights based on women's physical strength by pointing out that while not all men were equal in strength or intellectual capacities, they did all possess "des mêmes droits."137 By contrast, Pognon states, women had only recently become able to be witnesses in civil acts such as marriage, death, and births. ${ }^{138}$ She then states that feminists' next goal was to become legal guardians, arguing that only women could fully comprehend how difficult it would be for a dying mother to be unable to entrust their children to a sister or female relative. ${ }^{139}$

In Pognon's view, this struggle was both reflected and exacerbated by married women's inability in France to own their own fortune, and Pognon accuses the French government of betraying its principle republican foundation by keeping "dans son code des articles aussi injustes." ${ }^{140}$ Finally, Pognon states that feminism at the time was preoccupied not only with women's economic situation but also their political rights, as

\footnotetext{
135 Rogers Brubaker, Citizenship and Nationhood in France and Germany (Boston: Harvard University Press, 2009), 103.

136 Maria Pognon, "Féminisme,” La Fronde (Paris), 9 December 1897, 2.

137 Ibid.

138 Ibid.

139 Ibid.

140 Ibid.
} 
lack of female representation in politics had led to measures that ensured women's rights being voted down by male voters. ${ }^{141}$

Also published on December 9 1897, Marie-Anne de Bovet's "Ménagères ou Courtisanes?" critiques the notion, stated in Guy de Maupassant's Manon Lescaut, that women were only good as courtesans or housewives ${ }^{142}$. More broadly, it argues against the notion that women were only capable of fulfilling domestic or sexual roles, and therefore incapable of intellectual pursuits or excellence surpassing that of men. ${ }^{143}$ Bovet uses Maupassant's rhetoric of women's roles in ancient Greece against itself, arguing that women were, in fact, the source of education and intellectual engagement for men. ${ }^{144}$ Bovet sarcastically notes how "strange" it was that Greeks entrusted their sons' education and their own philosophers' and captains' intellectual growth to women and hetaerae respectively. ${ }^{145}$ Bovet combats the notion that women are incapable of being intellectuals and mothers, or authors and lovers, and suggests a simple test to judge women's intellect: "Si ce qu'une femme écrit est bon, on le lit, sinon on le laisse." 146 This article reflects women's struggle to be taken as seriously as intellectuals and writers as their male counterparts.

La Fronde's contributors were not concerned only with women's status within France, but also with the status of women internationally. As part of its focus on international affairs, La Fronde reported on feminist news from around Europe and the world. As with other international news, much of its commentary on feminism and

\footnotetext{
141 Ibid.

142 Marie-Anne de Bovet, "Ménagères ou Courtisanes?" La Fronde (Paris), 9 December 1897, 1.

143 Ibid.

144 Ibid.

145 Ibid.

146 Ibid.
} 
women's status internationally focused on European and French colonial matters. Indeed, while $L a$ Fronde's commentary and reporting on international affairs beyond the realm of feminism extended from the United States to Japan, its feminist commentary remained mostly focused on French colonial territories and interests or other European countries.

The paper's feminist commentary did pay significant attention to feminism and women's status in Germany, dedicating a three-day study in "La Tribune" to German feminism in its first month of publication. "Le Féminisme Allemand," which ran from December 21 to December 23 1897, provided an overview of feminism's place in Germany, including clearly defined types of German feminism. Class and social position determined the categorization of German feminists into three types: conservative, progressive, and socialist. ${ }^{147}$

Other commentary on women's issues in Germany appeared in the regular column "Chronique Féministe" on August 15 1898. In it, Camille Belilon reports on a club in Berlin in which women dressed and acted as men, including wearing false moustaches. ${ }^{148}$ Reflecting La Fronde's bridge between feminism and femininity, Belilon criticizes "cette ignoble mascarade" 149 and notes her relief that such a phenomenon was not present in Paris. ${ }^{150}$ This article suggests that the relationship between feminism and femininity was important to frondeuses other than Durand. Maggie Allison claims that Durand's femininity “compromises" La Fronde's feminist mission151 in "Marguerite Durand and La Fronde: Voicing Women of the Belle Epoque". Conversely, Mary Louise

\footnotetext{
147 D'Kaethe Schirmacher, "La Tribune: Le Féminisme Allemand," La Fronde (Paris), 22 December 1897, 2.

148 Camille Belilon, “Chronique Féministe," La Fronde (Paris), 15 August 1898, 3.

149 Ibid.

150 Ibid.

151 Allison, "Marguerite Durand and La Fronde," 40.
} 
Roberts argues that, for Durand, feminism was "a political enterprise that $[\ldots]$ was advanced by feminine wiles," 152 and that Durand's traditional femininity made feminism more palatable to conventional bourgeois audiences. Thus, Belilon's article, while potentially jarring in light of modern analysis, further reflects the multitude of political and social points of view present in feminist commentary in La Fronde. Belilon's defense of femininity also strengthens Chapman's argument that La Fronde blended femininity and feminism through its content and broader politics.

Germany was not the only European country whose women and feminists were featured in La Fronde. Published on July 15 1898, "Le Féminisme en Suisse" reported on feminist calls for educational equality in Switzerland, particularly with regard to vocational schools for young girls. ${ }^{153}$ In it, Clotilde Dissard praises Switzerland's move toward supporting young women's vocational training, noting that the Swiss state had given grants to schools in Neuchâtel, which put the canton in first place for number and variety of vocational schools. ${ }^{154}$ Dissard also discusses debates among men regarding women's vocational training, noting that while some felt it was below women's capabilities to run a school, others argued for the possibility of female directors of vocational schools in Switzerland and elsewhere. ${ }^{155}$ Dissard's article showcases international feminist movements as successful and influential, stating that Switzerland's education reforms with regard to vocational schools happened in no small part because of the efforts of Swiss feminist organizations. ${ }^{156}$ Dissard may have hoped to inspire French feminists fighting for education reforms with this article. She notes that only one city in

\footnotetext{
152 Roberts, Disruptive Acts, 50.

153 Clotilde Dissard, "Le Féminisme en Suisse," La Fronde (Paris), 15 July 1898, 3.

154 Ibid.

155 Ibid.

156 Ibid.
} 
Switzerland remained without a vocational school for women and that the move toward women in vocational schools generally was also supported by Swiss men.

Discussions of feminism on an international scale may have been intended to inspire women, regardless of whether they identified as feminists, to make similar changes in domestic affairs. That is, by reporting on feminist successes abroad, $L a$ Fronde provided French feminists with precedents with which to justify their demands for equality within France. Reports on international feminist movements and victories also worked to make La Fronde's readers aware of the international feminist community. Whether its readers all identified as feminists or not, the paper's reports on international feminist movements connected its readers to a broad community of women and further showcased the diversity of international feminist movements.

Unlike much of its other international and domestic reporting, La Fronde's feminist commentary did not necessarily insert itself into spaces it did not already occupy. Feminism in Paris was already a heterogeneous movement, whose adherents did not always agree with one another about its scope or methods. La Fronde's feminist success in this sense, then, was that it represented multiple points of view, including those with which its readers might not all agree. It would be difficult to argue that $L a$ Fronde gave equal representation to all feminist and women's rights issues. Yet, by representing a multitude of opinions and movements, both in France and elsewhere, the paper was able to enter into multiple feminist spaces and engage with multiple feminist debates. 


\section{Conclusions}

Despite not being an exclusively feminist newspaper in terms of its content, $L a$ Fronde and its contributors, editors, and publishers still resisted restrictive expectations for women in fin-de-siècle Paris. The woman-centric project at the heart of La Fronde was not necessarily to report exclusively on feminism, nor was it to report only news that men deemed appropriate for women. Rather, its project was to create a newspaper by women, for women. Containing a multiplicity of opinions and representing multiple viewpoints, La Fronde existed as a female invasion of a profession traditionally controlled by men, and of a space within society predominantly occupied by men. Its content included commentary on class divides, reporting on both international and domestic affairs (whether they applied directly to women's issues or not) and feminist commentary on domestic and international levels. While historians have often characterized La Fronde as an explicitly feminist publication, ${ }^{157}$ its project and function were more complicated.

By taking up space in a traditionally male sector such as journalism, Durand and La Fronde were able to insert women's voices into a broad array of issues and debates. This was not necessarily with the intent of "voicing women", as Maggie Allison claims. ${ }^{158}$ Rather, La Fronde provided its readers with a professional Dreyfusard paper159 that commented on the issues of the day. Allison states that La Fronde's explicit purpose was to further the cause of feminism ${ }^{160}$, and this may be true of Durand's intentions in the paper's creation. Its extensive feminist commentary and all-female staff were

157 See: Holmes \& Tarr, A 'Belle Epoque'?, 11-50.

158 Allison, "Marguerite Durand and La Fronde," 37-50.

159 Roberts, Disruptive Acts, 108.

160 Allison, "Marguerite Durand and La Fronde," 39. 
certainly intentional, but La Fronde, as a daily publication, contained content more complicated and varied than a simple presentation of feminist commentary.

Allison's analysis of La Fronde as a feminist paper is somewhat ahistorical, given that much of its "feminist content" 161 was feminist because women were writing it, not because of an explicit political feminism inherent in the articles. This is true of Sévérine's contribution to La Fronde. While it can be called feminist that a woman was providing regular political and social commentary on a newspaper's front page at all, the actual content of her writing did not contain a great deal of explicit feminist commentary.

Similarly, that La Fronde combined sober, and sometimes dry financial news with feminine advertisements and theatre news does not necessarily reflect internal contradictions. Rather, it suggests that La Fronde's editors and contributors were aware that its readers had diverse interests, and that women could be interested both in financial matters and in 'feminine' consumer goods such as diet pills and whitening toothpaste. Its recognition of multiple class interests for women functions in a similar way; though its direction and readership was largely middle-class, La Fronde contained extensive commentary and reporting about working-class women's issues. This reflects the economic diversity that characterized Parisian feminist communities. ${ }^{162}$ Rather than ignoring this divide or only representing their own middle-class positions on women's issues, La Fronde's editors and contributors represented what Máire Cross calls "a critical feature of feminism": its heterogeneity. ${ }^{163}$

\footnotetext{
161 Ibid., 38.

162 Cross, “1890-1914: A ‘Belle Epoque’ for Feminism?,” 33.

163 Ibid., 32.
} 
Cross notes that many women who sought expanded rights "did not question the rules of a man's world." 164 La Fronde, on the other hand, not only explicitly questioned the rules of a man's world but also challenged them openly by inserting themselves into debates otherwise restricted to men and male politics. By invading these debates and either pairing or infusing them with feminist commentary, La Fronde succeeded in its goal of creating a professional newspaper that also represented a multiplicity of feminist views. By using journalism as their medium, the women of La Fronde took up space in traditionally male sectors and debates and made that space their own as part of their resistance to political, economic, and social forces that sought to limit them.

La Fronde also occupied a place within feminist spaces, by not only representing a diverse range of women - economically and socially - but also by publishing articles that represented a range of feminist politics and opinions. As Cross notes, feminism in France at the turn of the century was "very far from being a single-issue pressure group around the vote." 165 By representing a broad array of feminist voices, La Fronde was able to enter into and engage with multiple feminist groups, some of whom undoubtedly disagreed with one another. Its focus on international feminist movements and victories also brought awareness of the global feminist community to its readers in Paris, thus connecting them to the wider movement.

In this way, La Fronde not only occupied space in traditionally male sectors such as politics and economics, but it also ensured that debates in these sectors occupied its readership's awareness. Through its diverse socio-economic, international, and domestic reporting, La Fronde engaged women in debates that, while not explicitly about feminist

164 Ibid., 31.

165 Ibid., 30. 
or women's issues, still affected them. La Fronde was a highly visible intrusion into the traditionally male sector of journalism, and its blending of sober journalistic reports and commentary with articles with a feminist slant ensured that its readers and French society were mutually aware of the important roles each played in the other's existence.

La Fronde contained multiple and occasionally contradictory points of view about feminism and women's issues, covering domestic, international, religious, and cross-class issues and representing a range of perspectives. Roberts argues that some of La Fronde's most well known contributors - including Sévérine, and Durand herself - were either "quiet about feminist matters"166 or held views unpopular with other feminists. Indeed, she states that Durand initially refused to label La Fronde as explicitly feminist. ${ }^{167}$ This refusal may not have been simply been due to personal politics or concerns, as Roberts implies. ${ }^{168}$ Rather, their resistance to regulatory gender norms and expectations seems to come through in the ways in which La Fronde blended feminist and non-feminist news, and did not adopt one single political stance with regards to the movement. By reporting on news that both explicitly and implicitly affected women, and pairing it with feminist commentary, La Fronde invaded the traditionally male sector of journalism and allowed women to participate in French political, legal, and social debates. Further, it reflected the diverse range of perspectives present among Parisian women and in Parisian feminist movements. Instead of occupying one firm political corner or attempting to carve out a separate niche for itself, La Fronde resisted regulatory gender norms by doing what malerun newspapers were doing, but doing it entirely without men.

\footnotetext{
166 Ibid., 9

167 Ibid.

168 Ibid., 8-9.
} 


\section{Natalie Clifford Barney, Renée Vivien, and Sappho: Tradition as Resistance, 1900-1910}

In the early years of the twentieth century, Paris's Left Bank began increasingly to play host to an expatriate Anglo-American population. A group of Anglo-American women who settled there became known as the "women of the Left Bank,"1 and they numbered among them visual artists, poets, playwrights, novelists, and actresses. Shari Benstock examined the contributions of Anglo-American expatriate women to Parisian literary society between 1900 and 1940 in Women of the Left Bank. ${ }^{2}$ Benstock's goal in this pioneering 1986 book was to emphasize the diverse and varied experiences and histories on Paris's Left Bank, and to resist "the reinforcement of that which in Western society serves as the norm: the privileging of the white, male heterosexual."3

Indeed, the women Benstock studied in Women of the Left Bank often resisted this norm. One such woman was Natalie Clifford Barney, ${ }^{4}$ a wealthy American who, with her British lover Renée Vivien, ${ }^{5}$ set about to resist heterosexual men's perspectives on their gender and sexuality. They did this by reinterpreting the works of Sappho, the ancient Greek poetess, and re-conceptualizing her tradition as one that featured same-gender desire and put a strong relationship to social space at its core. By re-making Sappho's tradition in a way that emphasized her relationship to Lesbos and her exclusive desire for women, Barney and Vivien resisted discourses that deemed them to be abnormal and isolated.

\footnotetext{
1 Shari Benstock, Women of the Left Bank (Austin, TX: University of Texas Press, 1986), 3.

2 Ibid., $i x$.

3 Ibid., $x-x i$

4 Ibid., 268-307.

5 Ibid., 277. Though Benstock includes Vivien in her list of "Women of the Left Bank," she does not dedicate a chapter to Vivien as she does to Barney.
} 
Born in Dayton, Ohio on October 31, 1876 to a wealthy American family, ${ }^{6}$ Natalie Clifford Barney, heiress to a railway fortune, relocated permanently to Paris in 1898. ${ }^{7}$ Shari Benstock notes that Barney knew from an early age that she was a lesbian, and became determined to not hide her sexuality. ${ }^{8}$ Barney's first romantic relationship, with Eva Palmer, ${ }^{9}$ helped spark her interest in antiquity. ${ }^{10}$ Once in Paris, Barney threw herself into Paris's social life. Specifically, she and Liane de Pougy, a courtesan, entered into a romantic relationship about which Pougy wrote a scandalous tell-all novel, published in $1901 .{ }^{11}$ In 1900, Barney met Renée Vivien and the two began a relationship almost immediately. ${ }^{12}$

Renée Vivien was born Pauline Tarn in London, England on June 11, 1877.13 Like Barney, Vivien relocated to Paris in order to escape the restrictions and expectations of both her family and the society in which she was raised. ${ }^{14}$ Unlike Barney's absolute insistence upon living openly and without shame, ${ }^{15}$ Vivien's life was plagued by depression, drug addiction, and alcoholism. In 1909, Vivien died, likely from complications of pneumonia exacerbated by her drug use and refusal to eat. ${ }^{16}$ In her life, Vivien wrote prolifically and, during her time in Paris, was open about her sexuality.

\footnotetext{
${ }^{6}$ Suzanne Rodriguez, Wild Heart: A Life: Natalie Clifford Barney and the Decadence of Literary Paris (New York, NY: Harper Collins, 2009), 46.

7 Ibid., 101-02.

8 Benstock, Women of the Left Bank, 272.

${ }^{9}$ Rodriguez, Wild Heart: A Life, 56-57

${ }^{10}$ Ibid. Palmer's interest revealed itself to be much more academic than Barney's; she dedicated herself to learning Greek in order to translate her favourite writings, and often dressed in the style of ancient Greeks.

11 Ibid., 114.

12 Ibid., 127.

13 Ibid., 129.

14 Ibid., 129-130.

15 Benstock, Women of the Left Bank, 272.

16 Rodriguez, Wild Heart: A Life, 210.
} 
Informing this analysis of how Barney and Vivien re-conceptualized Sappho's tradition is Eric Hobsbawm's theoretical approach to invented tradition. In The Invention of Tradition, Hobsbawm demonstrated how many traditions that appeared to have ancient roots had been fact been developed recently and were in some cases entirely invented. ${ }^{17}$ The Invention of Tradition offers multiple examples of how traditions such as Scottish Highland culture and rituals around sports were invented and how they sought to "establish continuity with a suitable historic past."18

Viewed in this light, Barney and Vivien's literary reworking of Sappho's tradition becomes an invented tradition. By rooting their same-gender desire historically and legitimizing it through a reworking and continuation of Sappho's legacy, they actively resisted prescriptive traditions by rewriting major events in Sappho's legend to focus on her desire for women and her relationship to Lesbos. In their effort to remake Sappho's tradition to suit this project, Barney and Vivien prioritized Sappho's desire for women, her power as a connecting force, and her centrality to Lesbos's community of womendesiring women.

Both Barney and Vivien sought liberation from restrictive social norms that dictated how they were to live their lives. Like Durand and her frondeuses, Barney and Vivien rejected the notion that they were destined for a life of heterosexual domesticity. ${ }^{19}$ Yet they did not explicitly advocate for feminist demands in their writing in the same way. As expatriates in Paris, they would not have benefited from the same legal and

\footnotetext{
17 Eric Hobsbawm, "Introduction: Inventing Traditions" in The Invention of Tradition ed. Eric Hobsbawm and Terence Ranger (Cambridge, UK: Cambridge University Press, 1983), 1. 18 Ibid.

${ }_{19}$ Benstock, Women of the Left Bank, 270.
} 
political advances as Durand and the frondeuses (who were Frenchwomen), and this may have explained why they were not involved in Parisian feminist movements.

While Durand and the frondeuses focused on resisting mainly political and legal restrictions associated with their gender, Barney and Vivien sought to resist social restrictions on both gender and sexuality. Barney and Vivien resisted social norms in a different way than Durand and the contributors to La Fronde resisted legal and political restrictions. Their resistance mainly took the form of reworking Sappho's historical character and re-conceptualizing her tradition to provide a basis from which they could legitimize and celebrate women's same-gender desire.

Rather than invading a traditionally 'male' sector such as journalism, Barney and Vivien continued Sappho's explicitly female and feminine tradition of creatively celebrating women's same-gender desire. This included rewriting, ${ }^{20}$ in the case of Barney, or refuting entirely, ${ }^{21}$ in the case of Vivien, accepted events in Sappho's legend, such as her fatal love for Phaon. ${ }^{22}$ In an attempt to re-create Sappho's Lesbos within Paris, Barney and Vivien also entangled Lesbos's geographical meaning with Sappho's significance as a woman who desired women. This attempt at space-making was never realized, because of the collapse of their relationship and Vivien's death in 1909. Nonetheless, Barney continued her attempts to live Sappho's tradition by positioning herself as a connecting force within her salon at 20 rue Jacob.

Barney and Vivien's re-conceptualizing of Sappho's tradition occurred within a specific historical moment. This historical moment saw a simultaneous rise in sexology's predominance and a renewed interest in antiquity. This increase in antiquity's

20 Natalie Clifford Barney, Equivoque in Actes et Entr'actes (Paris: E. Sansot et cie, 1910).

${ }^{21}$ Renée Vivien, Sapho (Paris: A. Lemerre, 1901).

22 Ibid. 
prominence, particularly among women, ${ }^{23}$ allowed readers, both scholarly and otherwise, access to Sappho's fragmentary poetry, leading to new interpretations of her works.

In the case of both Barney and Vivien, but especially Vivien, literature, poetry, and plays provide valuable historical insight into their motivations in the absence of other significant autobiographical sources from the time. In the absence of any autobiographical writing, Vivien's poetic and literary work stands as the only source of insight into her social views and personal motives. Barney, despite having published her memoirs in $1960,{ }^{24}$ wrote extensive works of semi-autobiographical fiction, poetry, and plays. This body of literature, published while Barney and Vivien were undertaking their project to rethink and re-create Sappho's tradition as a lesbian poet, is as important as Barney's memoirs in providing insight into the ways in which Barney and Vivien conceived of and used Sappho's tradition, and into their own histories as lesbians.

\section{Morals and Medicine: Sexology}

The practice of sexology, the scientific study of human sexuality, began in the mid-1800s with studies on prostitutes and prostitution in Paris. This area of study gained real traction later in the century, however, with the work of Richard Freiherr von KrafftEbing and Havelock Ellis. Krafft-Ebing was a German psychiatrist who is most well known for his work on sexology and its application in forensics. ${ }^{25}$ His 1886 work Psychopathia Sexualis presented a study of various sexual behaviours, and has been credited with coining the terms sadism and masochism. ${ }^{26}$

\footnotetext{
${ }^{23}$ Shanyn Fiske, Heretical Hellenism: Women Writers, Ancient Greece, and the Victorian Popular Imagination (Athens, OH: Ohio University Press, 2008), 5.

${ }^{24}$ Natalie Clifford Barney, Souvenirs Indiscrets (Paris: Flammarion, 1960).

25 Richard Freiherr von Krafft-Ebing, Psychopathia Sexualis ed. Victor Robinson (New York, NY: Pioneer Publications, 1939).

${ }^{26}$ Ibid.
} 
Krafft-Ebing's conclusions regarding non-reproductive sexuality - which, for him, included homosexuality, lack of desire, hypersexuality, and masturbation - were that any sexual activity not in line with propagation was necessarily perverse. ${ }^{27} \mathrm{Krafft}-$ Ebing thus concluded that same-gender attraction and sexual activity in men was a biological anomaly, causing the brain to undergo sexual inversion. He also argued that it could be considered a moral vice associated with masturbation. ${ }^{28}$ This separation into two categories through which he claimed people "acquired" 29 same-gender desire allowed for both a moral and pathological explanation and reaction to same-gender desire.

Most relevantly to the lives of Barney and Vivien, Krafft-Ebing also studied same-gender desire in women, in a section titled "Lesbian Love," ${ }^{30}$ which he situated within a category regarding pathological sexualities in their legal contexts. Krafft-Ebing associated this lesbian love, which he referred to as "forbidden friendships,"31 specifically with prisons for women and prostitution. ${ }^{32} \mathrm{He}$ also stated that, contrary to same-gender desire in men, women who experience same-gender desire acquired it due to extenuating circumstances. ${ }^{33}$ Krafft-Ebing quoted the 1837 French study of prostitution by Alexandre Parent-Duchatelet ${ }^{34}$ to argue that men's behaviour toward prostitutes in Paris is what drove them to relationships with other women. ${ }^{35}$

\footnotetext{
27 Ibid., 286.

28 Ibid.

${ }^{29}$ Ibid.

30 Ibid., 607.

31 Ibid.

32 Ibid.

33 Ibid.

34 Ibid.

35 Ibid., 608. This association further links women's same-gender desire directly to a 'social vice.'
} 
Both Parent-Duchatelet and Krafft-Ebing agreed that in women, same-gender desire was a "cultivated vice" 36 rather than a biological phenomenon, ${ }^{37}$ unlike men's same-gender attraction, which could fall into both categories. The section's inclusion of a category regarding the legality of sexuality, situated between a description of "cultivated pederasty" 38 and one of necrophilia, ${ }^{39}$ served to strengthen the moral condemnation inherent in Krafft-Ebing's study of same-gender desire in women. That it mentions the biological aspect of women's same-gender desire only in passing ${ }^{40}$ and only once compared it to same-gender desire in men, ${ }^{41}$ suggests that Krafft-Ebing was more interested in the moral and criminal aspects of lesbianism than in finding its source or explanation.

Havelock Ellis's study of human sexual behaviour and desire provided a more nuanced analysis of case studies than did Krafft-Ebing's. Ellis argued that his study presented a solely pathological analysis of the phenomenon of same-gender attraction in both men and women. In a reprinted preface to the first edition of Sexual Inversion, Ellis stated that he did not intend to publish a study of an "abnormal manifestation of the sexual instinct before discussing its normal manifestations," ${ }^{42}$ but that by doing so he had allowed himself more time to study so-called normal sexuality. 43

\footnotetext{
36 Ibid., $607 .$.

37 Ibid.

38 Ibid., 585-606.

39 Ibid., 611.

40 Ibid., 608-09. Krafft-Ebing seems to doubt that there is any psychological or physiological basis for same-gender desire in women, and focuses heavily on it as a "cultivated vice." 41 Ibid., 608. Krafft-Ebing notes that "as men abhor pederasts," women abhor tribadists. This is the only comparison between male and female same-gender desire in the section. ${ }^{42}$ Havelock Ellis, Sexual Inversion $3^{\text {rd }}$ edition (Philadelphia, PA: F.A. Davis Company, 1925), v. ${ }^{43}$ Ibid.
} 
While the study itself did not refer to same-gender attraction using overly moralistic language, Ellis stated that before he conducted his study he had "been inclined to slur it as an unpleasant subject." 44 Indeed, Ellis stated that he only committed to studying it in depth upon learning that "several persons for whom [I] felt respect and admiration were the subjects of this congenital abnormality," ${ }^{45}$ and that he came to the conclusion that England in particular punished same-gender desire overly harshly. ${ }^{46}$ Ellis argued that medicine, and indeed all of England, needed to make itself aware of 'sexual inversion,' as it was likely that many high-ranking members of English society - both male and female - experienced such desires ${ }^{47}$ and felt them to be "natural and normal." 48

Though Ellis did not directly refute the notion that same-gender attraction could possibly be something acquired later in life, he argued that if it was not always "inborn," 49 it certainly manifested itself instinctively and at an early age. ${ }^{50}$ Krafft-Ebing's work sought to understand sexual behaviour for the sake of understanding the "underlying conditions" 51 and was intended for forensic work. It explicitly associated same-gender desires with crime and vice. Ellis's, on the other hand, explicitly stated that the subjects of his study were neither in prison nor in asylums. ${ }^{52}$ His subjects "live in freedom, some of them suffering intensely from their abnormal organization, but otherwise [are] ordinary members of society." ${ }^{53}$ For Ellis, same-gender attraction was an

\footnotetext{
${ }^{44}$ Ibid.

45 Ibid.

46 Ibid.

47 Ibid., vi.

${ }^{48}$ Ibid., $v$.

${ }^{49}$ Ibid., vi.

50 Ibid.

51 Ibid., v.

${ }^{52} \underline{\text { Ibid, }}$, vi.

${ }^{53}$ Ibid.
} 
abnormality that could be pathologized; that said, those who experienced it were not necessarily criminals or mentally unstable. ${ }^{54}$ Rather, he argued that it was specifically because so many ordinary members of English society experienced it and considered it to be natural and normal that he was compelled to conduct his study. ${ }^{55}$

Like Krafft-Ebing, Ellis dedicated an entire section to "Sexual Inversion in Women." ${ }^{56}$ However, unlike Krafft-Ebing, Ellis did not differentiate significantly between same-gender desire in men and women, asserting that, for the most part, "[female homosexuality] runs [...] a parallel course to male homosexuality." 57 However, his argument that female same-gender desire flourished in "colleges and convents and prisons" 58 was in line with Krafft-Ebing's assertion that same-gender desire in women could be brought about through extenuating circumstances.

He also noted that women committed more crimes based on same-gender desire than men. ${ }^{59}$ Ellis supported this statistic by stating that while crimes by women generally are outnumbered by crimes by men, ${ }^{60}$ "in the homosexual field, as we might have anticipated, these conditions are to some extent reversed." 61 His justification for such a claim was that "inverted men"62 possessed a "feminine temperament" 63 and thus were less prone to violence, whereas "inverted women" 64 were of "masculine energy" 65 and

\footnotetext{
${ }^{54}$ Ibid.

55 Ibid., $v$.

56 Ibid., 195-263.

57 Ibid., 195.

58 Ibid.

${ }^{59}$ Ibid., 201.

60 Ibid.

${ }^{61}$ Ibid.

62 Ibid.

${ }^{63} \mathrm{Ibid}$.

64 Ibid.

${ }^{65}$ Ibid.
} 
therefore were more likely to commit violent crimes of passion such as murder.66 Though Ellis claimed not to moralize in his study of same-gender desire, his analysis of womendesiring-women as inherently violent contributed to the demonization of women's samegender desire, and his study contributed more broadly to the pathologizing of women's desire for other women.

Sexology was also responsible for the shift in moralistic and pathologizing language regarding perversity and vice. Anna Katharina Schaffner associates the shift toward a sexualized meaning of 'perverse' with the work of "German, French and English psychiatrists, doctors and psychologists in the second half of the nineteenth century." ${ }^{\circ 7}$ Sexology medicalized homosexual desire, turning it into a condition that needed treatment, or a category of classification that warranted scientific study. ${ }^{68}$

These semantic shifts happened simultaneously to the medicalization and pathologizing of sexuality; those who experienced or expressed same-gender attraction were considered to be either physically or mentally ill. They also were deemed to be 'perverts,' whose desires needed to be studied or corrected. The "homosexual" and the "pervert" became one and the same,${ }^{69}$ and those who fell into these new categories of classification were subject to medicalized and pathologizing discourse and action. ${ }^{70}$ More directly relevant to Barney and Vivien's lives, Krafft-Ebing's analysis of female homosexuality would have pathologized women who desired women, and the moralistic approach of Psychopathia Sexualis associated their desires with moral

\footnotetext{
${ }^{66}$ Ibid.

67 Anna Katharina Schaffner, Modernism and Perversion (Houndsmills, Basingstoke, Hampshire, UK: Palgrave Macmillan, 2012), 4

68 Ibid.

${ }^{69}$ Ibid.

${ }^{70}$ Ibid.
} 
depravity. Though same-gender desire and action between women was not illegal in many cases,${ }^{71}$ legal and scientific analyses had associated lesbianism with vice. ${ }^{72}$ Such associations, and the formation of a pathological and/or medical category with which to distinguish lesbian women, contributed to stigma and suspicion regarding relationships between women that may previously have been considered nonsexual or unthreatening.

Thus, women who desired women presented a sort of double anomaly: not only did they experience sexual attraction, which was thought to be unusual for women, it was sexual attraction that was, by sexological standards, a deviation from the 'normal' or 'healthy' sexuality displayed by exclusively heterosexual women. Female homosexuality in sexology also posed a different problem than that of male homosexuality; while in many countries male homosexuality was illegal, female homosexuality was generally not prosecuted as a crime. ${ }^{73}$

Ellis noted that because female closeness was socially accepted and even expected, ${ }^{74}$ it was difficult for sexologists to differentiate between close friendships between women and sexual relationships. ${ }^{75}$ Therefore, some sexological theories, including Ellis's, posited that so-called "inverted" women could be discovered by physiological means. ${ }^{76}$ This theory presumed that the bodies of women who desired women - or acted on such desires - were deformed or abnormal and thus markers of

\footnotetext{
${ }^{71}$ Krafft-Ebing, Psychopathia Sexualis, 607.

${ }^{72}$ Krafft-Ebing quotes Parent du Châtelet's study on prostitution and its association with lesbianism in his section on "Lesbian Love," and Ellis discusses the association between women's same-gender desire and violent crime.

${ }^{73}$ Despite being often associated with social vice or violent crime.

74 Ellis, Sexual Inversion, 204. As compared to similar closeness between men.

75 Ibid. Ellis's study generally makes itself aware of social expectations he suggests could lead to same-gender desire amongst women, such as closeness amongst women and the expectation that women avoid men except for when courting.

${ }^{76}$ Ibid., 251-56.
} 
"inversion". ${ }^{77}$ Often such "abnormalities" were uncovered after a woman had admitted to relationships with other women, and were assumed to have been either caused by or related to her sexuality. ${ }^{78}$

In Female Sexual Inversion, her study of Italian and British sexology, Chiara Beccalossi describes how sexologists and physicians made links between female sexual "inversion" and physiologically masculine traits, such as broad shoulders or small breasts. ${ }^{79}$ Ellis makes these connections in Sexual Inversion, stating that "inverted women" were more physically masculine and grew more body hair than "normal women." 80 Sexologists were able in their case studies to craft a method for identifying female "inverts" based heavily on physiological characteristics of those already identified as such. ${ }^{81}$ This made "inverted" women theoretically more recognizable. Women's samegender desire became linked to physiological traits that separated them from so-called "proper" (and, by implication, properly formed) heterosexual women. ${ }^{82}$

Natalie Clifford Barney rejected turn-of-the century theories about sex and sexuality. Her beliefs - that her lesbianism was not wrong, harmful, or unnatural ${ }^{83}-$ opposed views expressed by such sexologists as Krafft-Ebing and Ellis. Barney seems to have been aware of, and disdainful about, theories that argued that her desire for women was an aberration or an illness. To resist such moralizing and pathologizing language

\footnotetext{
77 Ibid.

${ }^{78}$ Chiara Becclossi, Female Sexual Inversion: Same-Sex Desires in Italian and British Sexology, c;1870-1920 (Basingstoke, UK: Palgrave McMillan, 2012), 4.

${ }^{79}$ Ibid., 3.

80 Ellis, Sexual Inversion, 254-55.

81 Beccalossi, Female Sexual Inversion, 4.

82 Ibid.

83 Benstock, Women of the Left Bank, 289. Quoted from Jean Chalon's Barney biography Portrait of a Seductress: The World of Natalie Barney (New York, NY: Crown Publishers, 1979), 47.
} 
regarding her sexuality, Barney and Vivien turned to Sappho, and began reconceptualizing her tradition.

\section{Rediscovering and Recuperating Sappho}

Around the same time that saw the rise of pathologizing narratives of so-called “abnormal" sexuality, interest in antiquity was also experiencing one of its many European resurgences. Specifically - and significantly for Barney and Vivien - Sappho's poetry was coming to light, both for scholarly and non-scholarly readers.

This interest in Sappho on the part of both scholars and non-scholars was not necessarily due to Sappho's interest in women. Much of it came from male scholars who admired Sappho's lyrical ability and were interested in the historical value of her fragments, while ignoring the usually overt desire for women within them. ${ }^{84}$ Some of this ignorance and/or deliberate misreading of Sappho's work that erases her desire for women can be historically traced. Jane Macintosh Snyder argues in Lesbian Desire in the Lyrics of Sappho that the erasure of Sappho's desire for women dates to Catullus and Ovid's ${ }^{85}$ respective translations and interpretations of her poems. ${ }^{86}$ Snyder notes that Catullus in particular appropriated Sappho's poetry to express his own male heterosexual desire. ${ }^{87}$ Macintosh Snyder further argues that many male scholars discussed Sappho's

\footnotetext{
84 Jane Macintosh Snyder, Lesbian Desire in the Lyrics of Sappho (New York, NY: Columbia University Press, 1997), 36.

${ }^{85}$ Ibid. Snyder notes that it is Ovid's Heroides that popularized the legend of Sappho leaping to her death after having been slighted by a man. Jane Macintosh Snyder doubts the historicity of this legend, as did Renée Vivien.

86 Ibid.

${ }^{87} \underline{\text { Ibid. }}$.
} 
poems as if they were all wedding odes, wherein she expressed her chaste and honourable love for the bride or celebrated a groom's romantic love for his bride. 88

Though late nineteenth-century scholarship about Sappho generally underplayed her desire for women, non-scholarly interpretations were more wide-ranging. Some nonscholarly readers, including Barney and Vivien, read Sappho's work as evidence of a long history of women who desired other women. ${ }^{89}$ For Barney especially, Sappho's work meant that she was part of a long history of women who acted upon their desires for other women and lived happily doing so. ${ }^{90}$ For Vivien and Barney, Sappho's samegender desire was central to her tradition, and this led them to re-conceptualize and use their version of her tradition in their time, with same-gender desire at its core.

Barney and Vivien were not the only women in fin-de-siècle Europe who were becoming more interested in antiquity. In Heretical Hellensim: Women Writers, Ancient Greece, and the Victorian Popular Imagination, Shanyn Fiske argued that Victorian women had become more and more interested in classical knowledge and literature, which she noted was, at the time, still considered the reserve of the male intellectual elite. ${ }^{91}$ Fiske describes women's self-education about the classics as "an endeavor that, for many [women], bore the urgency and excitement of sexual awakening"92 due in part to its forbidden or inaccessible nature.

\footnotetext{
88 Ibid., 29-30. As opposed to her own romantic or erotic love for the female subjects of her poetry.

89 Rodriguez, Wild Heart: A Life, 77.

90 Ibid.

91 Fiske, Heretical Hellenism, 5.

92 Ibid.
} 
Fiske suggests that this "erotic appeal of forbidden knowledge" 93 was heavily associated with the classics, which were considered mandatory learning for men but forbidden (even heretical) for women. ${ }^{94}$ The taboo nature of the classics in the mid- to late-Victorian period combined with the subject matter of Sappho's poems could have easily made women's interest in her work doubly appealing. Sappho's fragmentary poetry represented both forbidden knowledge and forbidden desires.

In Women of the Left Bank, Shari Benstock noted that many of Barney’s biographers have focused on Barney's lesbianism as a sort of gossip ${ }^{95}$ or as something exclusively relegated to her social life. ${ }^{96}$ But her sexuality seems to have influenced her intellectual work on the recuperation of Sappho as a woman-desiring-woman and her recreation of Sappho's community in turn-of-the-century Paris. Benstock noted that Barney objected outright to negative emotions such as anger and self-pity associated by many with lesbianism ${ }^{97}$ and objected to the imitation of masculine dress and behaviour, 98 suggesting that she was untouched by a "parent culture that despised evidence of sexual difference, defining it as perversion."99 This rejection of masculinity as an expression of sexual desire also opposed sexological theories that associated physiologically masculine features with same-gender desire in women. ${ }^{100}$

Barney resisted discourses that posited lesbianism as a physiological or mental disorder, secure in her mission to recuperate lesbian desire as something healthy, natural,

\footnotetext{
93 Ibid.

94 Ibid.

${ }_{95}$ Benstock, Women of the Left Bank, 10.

${ }^{96}$ Ibid.

${ }^{97}$ Ibid., 11.

98 Ibid.

99 Ibid.

${ }^{100}$ Beccalossi, Female Sexual Inversion, 3-4.
} 
and worth celebrating through her use of Sapphic tradition. Benstock rightly argued that this insistence upon lesbianism as healthy and worth celebrating set Barney apart from many other lesbians of her time ${ }^{101}$ and suggested that her feminism, social class, and intellectual interests may have had a hand in how differently she approached her expression of lesbianism. ${ }^{102}$

Her interactions with male readers and re-interpreters of Sappho's work and life, Benstock argued, required a collaboration with male points of view that allowed Barney to then reinterpret Sappho's life and work in her own way. ${ }^{103}$ Benstock stated that once Barney had drawn what she needed from her male mentors - particularly Louÿs, who served as her long-ignored editor ${ }^{104}$ - she "set aside their advice, ignored their cautionary directives, and continued the direction she herself had determined."105 Vivien, like Barney, engaged with interpretations of Sappho's work that posited the poetess as heterosexual only to refute such claims in Sapho, her 1901 biography and poetic collection. ${ }^{106}$

Both Barney and Vivien took aspects of contemporary interpretations of Sappho that suited their project, but ignored those which did not fit or with which they disagreed in order to craft a Sapphic tradition that they could apply to their own lives. Barney outright refuted sexological theories about lesbianism, stating that her sexuality "isn't a vice, isn't 'deliberate,' and harms no one."107 For Barney, lesbianism was a state

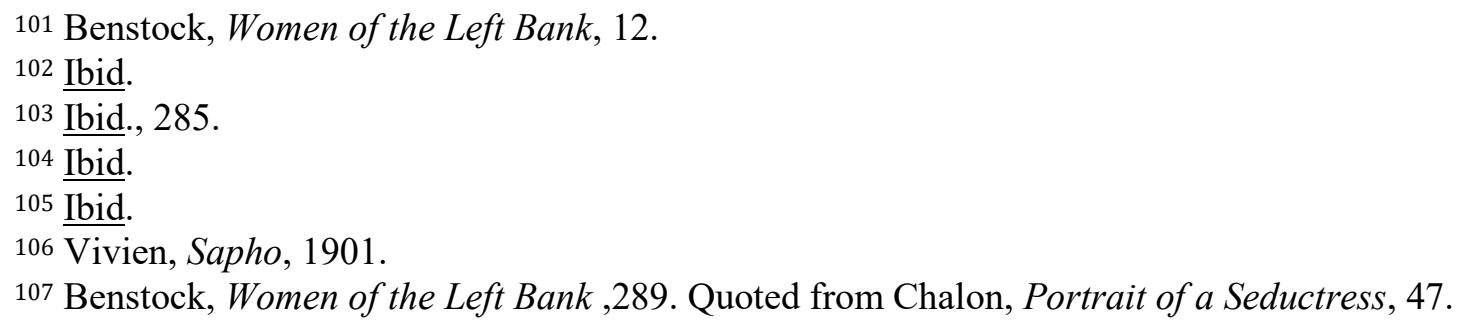


"produced by nature." 108 By contrast, she felt that heterosexuality was impure and dangerous for women, ${ }^{109}$ because it "made woman a victim of man's desire," 110 whereas same-gender desire allowed women to control their own bodies and desires. ${ }^{111}$

In The Amazon and the Page, her dual biography of Barney and Vivien, Karla Jay provided a literary examination of Barney and Vivien, in resistance to their role as "spicy literary footnotes." 112 Like Benstock, Jay critiqued biographies and analyses of Barney and Vivien that simplified their lives as gossip or anecdote. ${ }^{113}$ Jay's analysis focused on Barney and Vivien's prolific literary output and their "woman-centered philosophy."114 Jay also argued that Barney and Vivien are remembered more for their love than for their writing. ${ }^{115}$ This analysis included examining Barney and Vivien's literary inspirations as well as the ways in which they challenged the literary conventions in which Jay argues they wrote. ${ }^{116}$ One of her chapters focuses specifically on the influence of Sappho's poetry on Barney and Vivien's work. ${ }^{117}$

In her analysis of Barney and Vivien's relationship to Sappho, Jay argued that both Barney and Vivien, in their worship of Sappho, recreated her "in [their] own

\footnotetext{
108 Ibid.

109 Ibid., 290.

110 Ibid.

111 Ibid.

112 Karla Jay, The Amazon and the Page: Natalie Clifford Barney and Renée Vivien (Indianapolis, IN: Indiana University Press, 1988), xi.

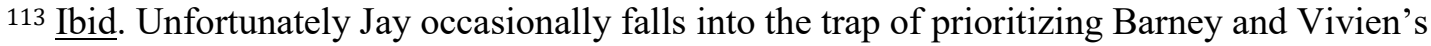
relationship while simultaneously critiquing other scholars who have done the same.

114 Ibid., xiv.

115 Ibid., 22-23. Jay also argues, ahistorically, that Barney and Vivien "transgressed the rules of family and convention before the word Lesbian was even in use." The word Lesbian had in fact come to refer to women-desiring women in the late $19^{\text {th }}$ century and was used by sexologists such as Krafft-Ebing.

116 Ibid.

117 Ibid., 61-80.
} 
image."118 This re-creation of Sappho in Barney and Vivien's own image was, Jay argued, a way of deifying Sappho in order to worship her as a goddess. ${ }^{119}$ Jay analyzed this re-creation in terms of Barney and Vivien's religion, reading it as "a goddesscentered version of Christian dualism," which reproduced in their re-creations "a truly masculine inheritance." ${ }^{20}$ Despite her argument that Barney and Vivien's re-creation of Sappho was inherently masculine due to its Christianity, Jay does acknowledge that they were attempting to find or create a "continuing female tradition." 121 Jay concluded that they succeeded in this posthumously and "created for themselves a permanent place as genuine foremothers of modern feminist literature." 122

Sappho's poetry and legacy were part of Barney and Vivien's project of recreating a community of creative lesbians in Paris, inspired by Sappho's own ancient community of women at Lesbos. This project would never be completed. However, their attempts involved tying Sappho inextricably to Lesbos, and attempting to do the same with their community and Paris. By entangling Lesbos's geographic meanings with Sappho's explicit lesbianism, Barney and Vivien sought to rethink the relationship between Sappho and Lesbos, and then attempted to apply that to their relationship with Paris. This attempt was part of their project of continuing the Sapphic tradition that they had rewritten and recuperated, which focused on Sappho's same-gender desire and put community at its core.

\footnotetext{
118 Ibid., 71.

119 Ibid., 70-71.

120 Ibid., 80.

121 Ibid., 81.

122 Ibid., 125.
} 


\section{Entangled Meanings: Sappho and Lesbos}

Attempting to emulate Sappho, Barney and Vivien's group of women writers reconceptualized Sappho's group of creative women in Lesbos as their own community within Paris. This re-creation of Sappho's community in their own time was not an invasion of a traditionally male social space, as in the case of Durand and La Fronde. Rather, Barney, Vivien, and their cohort were inspired by Sappho's exclusive community of women to attempt to create a separate space $^{123}$ where women were able to creatively celebrate their desire for other women.

In Barney and Vivien's works, Sappho and Lesbos were inextricably entangled. Barney and Vivien's contemporaries used both to make reference to the same concept: lesbianism. Barney writes of Sappho as a connecting force for women who desired women, in the dialogue "Douces rivalités,"124 and the play "Équivoque."125 In “Équivoque," Barney also rewrites the tradition of Sappho's death, reworking the myth to be about Sappho's same-gender desire and her role as the centre of a community at Lesbos.

Published in her collection of Greek-inspired works Cinq petits dialogues grecs, Douces rivalités features Sappho as a connecting force between Ione and the women who love her. ${ }^{126}$ Ione, who bemoans to her friend Eranna ${ }^{127}$ that her lover Myrclis has abandoned her and gone to Mytilene after an attempt by Ione to incite jealousy gone

\footnotetext{
123 Benstock, Women of the Left Bank, 12.

124 Natalie Clifford Barney, Douces Rivalités in Cinq petits dialogues grecs (Paris: E. Sansot et cie, 1910), 11.

125 Natalie Clifford Barney, Équivoque in Actes et Entr'actes (Paris: E. Sansot et cie, 1901), 4981.

126 Barney, "Douces Rivalités," 11-44.

${ }^{127}$ Ibid., 11. Ione refers to Eranna as "ma petite amie," however given the plot of the play it is difficult to discern whether their relationship is romantic or if it is a pet-name.
} 
awry, eventually herself travels to Lesbos. ${ }^{128}$ When Ione and Eranna travel to Mytilene, Ione and Myrclis happily reunite, only for Myrclis to suggest that Eranna is also in love with Ione. ${ }^{129}$ While Sappho is not directly responsible for this revelation, it is only once they reach Mytilene that Eranna's desire for Ione is brought into the open, and only there is Ione's desire for women depicted in any way other than tragic. Indeed, that Ione was required to travel to Mytilene in order to happily reunite with Myrclis ${ }^{130}$ further reinforces the island's status in Barney's work as a place where women's same-gender desire is specifically positive and celebrated. While Sappho is not physically present in the dialogue, her spirit and reputation lingers throughout its action. Through its association with Sappho, Lesbos and specifically Mytilene become imbued with her power to bring together women who experienced same-gender desire. ${ }^{131}$ In Équivoque, a play published in Barney's 1910 anthology Actes et Entr'actes about the death of Sappho, Barney rewrites the story of Sappho's love for Phaon, a boatman, and her subsequent death. ${ }^{132}$ As in Douces rivalités, much of the play's focus is on Sappho's impact on other women who desired women. However, the catalyst of the play is a rewritten version of Sappho's death due to her love for Phaon. Instead of throwing herself from a cliff because of unrequited love for Phaon, Barney's theatrical Sappho ends her life because she loves Phaon's bride Timas. ${ }^{133}$ Barney's version of Sappho's death still involves her killing herself over unrequited love, but Barney reworks the tradition in order to emphasize Sappho's desire for women.

\footnotetext{
128 Ibid., 43-44.

129 Ibid., 36.

130 Ibid., 32.

131 Barney, Douces Rivalités and Équivoque.

132 Barney, Équivoque, 49-81.

133 Ibid., 68-69.
} 
Équivoque's second act is dedicated to a description of women coming together to mourn Sappho, including Timas and multiple women from outside Lesbos. ${ }^{134}$ It is in this way that Barney once again conceptualizes Sappho's tradition as a connecting force that is associated with Lesbos regardless of whether she is there or not. After learning Sappho has died, the women remain at Lesbos and vow to continue Sappho's legacy so that she may live on in her poetry. ${ }^{135}$ How Sappho and her followers are portrayed in Équivoque rewrites Sappho's tradition in a way that, while adhering to some aspects of her myth, also recontextualizes her as an explicitly same-gender desiring woman whose community at Lesbos was so important that it lived on even after her death. ${ }^{136}$

Barney also connected Sappho with Lesbos in her poetic work. In Sonnet, the poetic preface to Cinq petits dialogues grecs, Barney writes an ode to Lesbos. ${ }^{137}$ In this poem, Barney demands that Lesbos take her revenge against "la Laideur immonde qui se nomme Vertu." ${ }^{\prime 38}$ The island is personified, with Barney speaking about its lips and addressing it as though it is a human being. ${ }^{139}$ It is only at the end of the poem that Sappho is mentioned by name, ${ }^{140}$ thus explicitly conflating her with Lesbos in Barney's poetic appeal. This collapsing of Sappho and Lesbos's meanings, to the extent of referring to them as one and the same being, ${ }^{141}$ further indicates the importance of Lesbos in their interpretations of Sappho. By collapsing Sappho with Lesbos in a way

\footnotetext{
134 Ibid., 73-75.

135 Ibid., 75.

136 Ibid.

137 Natalie Clifford Barney, Sonnet, in Cinq petits dialogues grecs (Paris: E. Sansot et cie, 1910), 10.

138 Ibid.

139 Ibid.

140 Ibid.

141 Ibid.
} 
that furthers Barney's own project and philosophy, Barney once again makes Sappho's tradition her own by adjusting and focusing on elements of it that suited her goals.

Vivien also rewrote Sappho's tradition in a way that emphasized both her relationship to Lesbos and her exclusive desire for women. In her 1901 biography and poetic collection, Sapho, Vivien describes Sappho as embodying "toutes les magnificences de la nature," 142 listing the terrestrial and astronomical phenomena with which she associates Sappho's persona. While Barney's representation of Sappho is intellectually tied to Lesbos, ${ }^{143}$ Vivien's Sappho is solidly rooted in her physical environment. Like Barney, however, Vivien's interpretation of Sappho's relationship to Lesbos is central to how Vivien characterizes her and rewrites her tradition.

In Sapho's brief biographical section, Vivien refers to Sappho as 'l'Aède de Lesbos," 144 further tying Sappho and Lesbos together in a description of lesbian desire. ${ }^{145}$ Vivien produces a history of Sappho as a member of the nobility in Mytilene, ${ }^{146}$ including the familial history that Vivien states Herodotus set down about Sappho, which posits Sappho as a member of an aristocratic and respectable family. ${ }^{147}$ Through this association Vivien furthers the relationship between poet and geography and lays a foundation of class-based respectability for Sappho. ${ }^{148}$ This respectability does not contradict her open desire for women in Vivien's account of her life, which contravenes associations between lesbianism and lower social classes. ${ }^{149}$

\footnotetext{
142 Renée Vivien, Sapho (Paris: A. Lemerre, 1903), iv.

143 Barney, Sonnet, 10.

144 Vivien, Sapho, viii.

145 Ibid.

146 Ibid.

147 Ibid.

148 Ibid.

${ }^{149}$ See: Krafft-Ebing, Psychopathia Sexualis and Ellis, Sexual Inversion.
} 
Due to the fragmented nature of Sappho's poetry (the only significant source of biographical information) and the diverse and contradictory myths surrounding her life, it is difficult to gauge the historical accuracy of Vivien's assertions about Sappho's aristocratic background. However, Vivien seems not to have been attempting to craft a strictly historical narrative about Sappho. Rather, her biography of Sappho reinforced her interpretation of Sappho's tradition, in which her community at Lesbos and her samegender desire play a central role.

Vivien also takes time in her biography of Sappho to describe the island from whence she came. This brief geographical interlude describes Lesbos as "la patrie de la volupté et du désir," 150 an island where the desire and excess ascribed to Sappho originates. Vivien goes on to describe the inhabitants' appearance; this description is one of the few places where she uses the term 'Lesbian', ${ }^{151}$ in this case to refer specifically to the population that inhabited Lesbos. In this description, Vivien ties Lesbos and its inhabitants inescapably to Sappho, using Sappho's purported features as an example of how all inhabitants of Lesbos appeared. ${ }^{152}$ This collapsing of all inhabitants of Lesbos to match the features allegedly unique to Sappho strengthens Sappho's integral relationship to Lesbos and, conversely, the island's integral relationship to the Sappho myth.

Rather than making an intellectual connection between Sappho and Lesbos, Vivien makes a tangible and ostensibly visual connection. ${ }^{153}$ By comparing all inhabitants of the island to Sappho, Vivien collapses Lesbos and Sappho in a way that is very different from Barney's comparison. Vivien implies that Sappho is the typical (or

\footnotetext{
150 Vivien, Sapho, xi.

151 Ibid.

152 Ibid.

153 Ibid.
} 
original) Lesbian. Additionally, Vivien ties Sappho to the Lesbian aristocracy; this association between class-based assumptions about respectability and same-gender desire resists sexological associations between lesbianism and the lower classes. ${ }^{154} \mathrm{By}$ combining Sappho's alleged place as a higher-class member of Lesbian society and positing her as the typical or original Lesbian (and lesbian, in the sexual sense), ${ }^{155}$ Vivien is able to strengthen Sappho and Lesbos's ties to one another and to exclusive samegender desire amongst women.

Also in Sapho's biographical section, Vivien disputes the legend of Sappho's death. Unlike Barney, Vivien does not solely change the details of Sappho's death. Rather, she argues that not only did Sappho not die out of for love Phaon, but also that Phaon did not even exist. ${ }^{156}$ Vivien engages directly with Sappho's tradition in this section, arguing that Phaon was nothing more than a "mythe créé par quelques écrivains d'après la tradition populaire." 157 By not only engaging with traditions about Sappho that posited her as desiring men but also outright refuting them, Vivien created her own version of Sappho's tradition. In Vivien's version, Sappho could not have possibly loved Phaon, because in Vivien's Sapphic tradition, Phaon did not exist and thus posed no threat to Sappho's desire for women. ${ }^{158}$ By refuting and immediately rewriting this aspect of Sapphic tradition, Vivien placed Sappho's desire for women at the centre of her tradition as a poet and figure of antiquity.

Barney and Vivien replicated aspects of Sappho's tradition that suited their project of recuperating and celebrating lesbianism in their own time. These aspects were,

${ }^{154}$ Krafft-Ebing, Psychopathia Sexualis and Ellis, Sexual Inversion.

155 Vivien, Sapho, xi.

156 Ibid., $x i$.

157 Ibid.

158 Ibid., ix-x. 
centrally, an insistence upon Sappho's exclusive desire for women ${ }^{159}$ and the importance of her relationship to Lesbos. ${ }^{160}$ Not all of what they wrote was grounded concretely in history. What they did choose to represent and re-create from Sappho's tradition validated and reinforced their identities as lesbians. This reworked tradition also allowed them to attempt to take their project one step further, by attempting to re-create the community from their version of Sappho's tradition in their own time and space.

\section{Paris: Re-Creating Sappho's Tradition}

Given that a central part of Barney and Vivien's re-conceptualized Sapphic tradition was Sappho's relationship to Lesbos, it is perhaps unsurprising that they attempted to re-create her community in Paris. Barney referred to this attempt in her 1960 memoirs Souvenirs Indiscrets, ${ }^{161}$ and most biographers of Barney and Vivien describe the attempt as part of their commitment to Sappho. This attempt ultimately failed due to the collapse of their relationship in 1904, ${ }^{162}$ which was followed by Vivien's death in 1909. After Vivien's death, however, Barney continued her attempts to re-create the Sapphic tradition she and Vivien had conceived.

One way in which Sappho's re-conceptualized tradition was re-created was through Barney's role in her salon at 20 rue Jacob. ${ }^{163}$ This salon, which ran from 1909 to 1970, was not exclusively for women, nor did it exclusively celebrate same-gender desire. However, the way in which Barney conceived of her role in the salon replicates

\footnotetext{
159 Vivien, Sapho and Barney, Équivoque.

160 Vivien, Sapho and Barney, Sonnet and Douces rivalités.

161 Barney, Souvenirs Indiscrets, 51.

162 Jay, The Amazon and the Page, 18.

163 Barney, Souvenirs Indiscrets, 11.
} 
the way in which she depicted Sappho: as an integral connecting force. ${ }^{164}$ That her selfperception so closely mimics her depictions of Sappho suggests an attempt to continue Sappho's tradition as she saw it within her social circle.

Though Barney and Vivien primarily interacted with Sappho through writing, Barney's identification with Sappho's tradition as a creative connecting force takes on a visual element in her 1929 sketch of her home at 20 rue Jacob, which housed her longstanding salon. ${ }^{165}$ The sketch depicts the house and grounds as seen from above; along with the rooms in her home where the salon meetings took place, she details the grounds and her "Temple à l'amitié" (so named for its dedication above the entrance). ${ }^{166}$

In the sketch, Barney includes attendees of her salon, drawn together and connected by a line that represents, with its title of l'amazone, ${ }^{167}$ Barney's path through the salon. ${ }^{168}$ This group of attendees includes such figures from Barney's love life as Élizabeth de Gramont, Romaine Brooks, and Renée Vivien, and claims a timeline of 1910-1930. ${ }^{169}$ Melanie Hawthorne notes that the connections Barney makes in the sketch do not necessarily reflect real-life connections made between the attendees. ${ }^{170}$

Gramont explicitly stated that she never met Vivien, and though Vivien and Brooks met, it was before either had met Barney ${ }^{171}$. There is also the issue of the sketch's timeline: Vivien's death predates it by a year, and the compression of every salon's

\footnotetext{
${ }^{164}$ Melanie Hawthorne, "Clans and Chronologies: The Salon of Natalie Barney", A 'Belle Époque'?: Women in French Society and Culture 1890-1914, ed. Diana Holmes and Carrie Tarr (New York, NY: Berghahn Books, 2007), 68.

165 Ibid., 67.

166 Barney, Souvenirs Indiscrets, 11.

167 Ibid.

168 Hawthorne, "Clans and Chronologies," 68.

169 Barney, Souvenirs Indiscrets, 11.

170 Hawthorne, "Clans and Chronologies," 69.

171 Ibid.
} 
attendee over a two-decade period cannot and must not reflect the realities of how the salon functioned. ${ }^{172}$

Melanie Hawthorne argues that a reflection of the real-life functioning of the salon may not have been the goal of Barney's sketch ${ }^{173}$. Rather, she suggests that Barney may have been tracing connections made through her relationships with those she includes in the sketch. ${ }^{174}$ These connections created, in effect, an imagined and imaginary community in which she was the connecting force. ${ }^{175}$ This compression of her salon's attendees across space and time suggests an attempt on Barney's part to present herself as a connecting force, through time and irrespective of social group, for all those represented by her map. The implication seems to be that it matters not when or from which group the attendees of Barney's salon came; what matters, in her view, is that she brought them together.

That Barney represented herself as a connecting force - someone who brought disparate individuals together to form a large group, irrespective of time and social group - directly mimics how she portrayed Sappho in Douces rivalités and in Équivoque. ${ }^{176}$ In both works, regardless of whether or not Sappho is physically present, she and Lesbos function as a connecting force between women experiencing conflict or who came from different areas. This aspect of Sappho's tradition is not only taken up by Barney in her literature, but also, through her representation of herself in the sketch, ${ }^{177}$ in her life. Though her salon was not an exclusive social space reserved for women-desiring women,

172 Ibid.

173 Ibid., 68

174 Ibid.

175 Ibid., 77.

176 Barney, Douces rivalités and Équivoque.

177 Hawthorne, "Clans and Chronologies," 67. 
she nonetheless took on Sappho's traditional role as a connector of individuals to form a group or community.

Additionally, Paris seems to have played a similar role for Barney and Vivien to the Lesbos that they represented in their respective works. The city's long association with cultural and intellectual liberation in comparison to much of the rest of Europe enabled the development of a space where Barney, Vivien, and other openly lesbian women could find acceptance and celebrate their desires. In "Paris-Lesbos: Lesbian Social Space in the Modern city, 1870-1940," Leslie Choquette describes the public social spaces occupied by lesbians in Paris before the Second World War. ${ }^{178}$ Choquette refutes the notion that lesbians in Paris were more "discreet and [...] private in their conduct," 179 and states that they instead enjoyed a flourishing public life. ${ }^{180}$

Despite the fact that lesbian subculture proves more difficult to trace than that of gay men through legal records, as lesbians were not a "suspect class," 181 Choquette argues that they became more visible due to the rise of sexology. ${ }^{182}$ This visibility allows historians to trace their public lives and subculture in Paris from 1870 onward. ${ }^{183}$ Choquette finds Paris's lesbian subculture in “a variety of public places: restaurants, bars, cafés, theaters, music halls, dance halls, brothels, boutiques, [...]" and so on. ${ }^{184}$

\footnotetext{
178 Leslie Choquette, "Paris-Lesbos: Lesbian Social Space in the Modern City, 1870-1940" in Proceedings of the Western Society for French History 26, ed. Barry Rothaus (Denver: University of Colorado Press, 1999), 122-32.

179 Ibid., 122. Quoting Michael Siblais, "Paris" in Queer Sites: Urban Gay Histories Since 1600, ed. David Higgs (New York: Routledge, 1998), 11.

180 Ibid., 123.

181 Ibid., 122.

182 Ibid., 122-23.

183 Ibid.

184 Ibid, 123.
} 
Though Choquette correctly categorizes Barney's salon as a private space - in that it took place in an individual's home - Paris had a thriving and publicly visible lesbian subculture by the time Barney and Vivien relocated to the city. Given this, it is not surprising that they viewed Paris as their own version of Lesbos: an idealized space in which their desires would be accepted and could be celebrated.

In her chapter "The Sapphist in the City: Lesbian Modernist Paris and Sapphic Modernity" in Sapphic Modernities, Joanne Winning discusses the ways in which Paris became overwritten with a mapped Sapphic social space. ${ }^{185}$ Winning uses the example of Sylvia Beach's bookshop Shakespeare and Company in conjunction with the salons of Paris in the interwar years in order to challenge narratives that suggest lesbians were placeless within urban spaces. ${ }^{186}$ For Winning, Sapphic modernists in Paris are entrenched in space, both geographical and social. Winning thus echoes Choquette's assertion that not only did lesbians have a place in Paris, but that they were also highly visible and involved in its public spaces. ${ }^{187}$

According to Winning, "modernist and Sapphic networks overwrite national boundaries." 188 Though not part of the modernist movement in the first ten years of the twentieth century, Barney and Vivien both sought to create a community inspired by Sappho's own that transcended the national boundaries of their time. As expatriates, both Barney and Vivien eschewed as much as possible their national origins, to the point where both wrote and lived almost exclusively in French. As well, not all members of

\footnotetext{
185 Joanne Winning, "The Sapphist in the City: Lesbian Modernist Paris and Sapphic Modernity" in Sapphic Modernities: Sexuality, Women and National Culture ed. Laura Doan and Jane Garrity (Basingstoke, UK: Palgrave Macmillan, 2006), 21-27.

186 Ibid., 21. Winning contrasts this "placelessness" with the overtly visual place of gay men in urban spaces, as suggested by Castells.

187 Choquette, "Paris-Lesbos," 128.

188 Winning, "The Sapphist in the City," 22.
} 
their community of Sappho-inspired women lived in Paris, and not all at the same time; their community itself transcended national boundaries.

Winning also describes Paris as a meeting place or place of sanctuary for samegender desiring women. ${ }^{189}$ In this way, Paris's social space may have functioned as an echo of Mytilene for Barney and Vivien. Just as Mytilene became entangled with Sapphic celebrations of same-gender desire amongst women, Paris became increasingly a place of pilgrimage for same-gender desiring women, wherein they could celebrate their desires and live more freely. Indeed, in Équivoque, both Ione and Eranna refer to Mytilene as a place of pilgrimage that allows for greater freedom and perhaps reconciliation of samegender lovers. Given this, Barney and Vivien's representation of Lesbos as inextricably entangled with Sappho's tradition of creative celebration of lesbianism takes on an important role in their attempts to re-create a Sapphic community in Paris.

Barney and Vivien's aspirational community based on Sappho's community at Lesbos never materialized. Despite this, Barney and Vivien both became associated with Paris's lesbian community through their openly expressed sexuality, their literature, and Barney's position at the centre of Paris's creative community. This association can be found in commentaries on their work and their place in Paris Left Bank. Djuna Barnes, for example, in Ladies Almanack, portrayed Barney as being central to a community of same-gender desiring women ${ }^{190}$ who, as in Barney's sketch of her imagined salon community, ${ }^{191}$ may or may not have all interacted with one another all at the same time.

\footnotetext{
189 Ibid., 20.

190 Djuna Barnes, Ladies’ Almanack (New York, NY: New York University Press, 1992, Reprint.) ${ }^{191}$ Hawthorne, "Clans and Chronologies," 67.
} 
This is in line with Barney's representation of Sappho as the connecting force between women-desiring women through time, even after Sappho's death. ${ }^{192}$ In this way, Barney was able to replicate and continue Sappho's tradition as a connecting force. This insistence upon Sappho's centrality and her ability to bring individuals together in community resists sexological narratives that depict lesbianism as inherently corrupting and isolating. ${ }^{193}$ By insisting upon Sappho's exclusive desire for women and pairing it with an insistence upon her centrality to Lesbos's community of women-desiring women (and Lesbos more broadly), Barney and Vivien re-made her tradition to suit their goals. It is clear that Vivien and Barney both viewed Paris as an ideal space in which their desires could be accepted and celebrated, and they attempted to locate their remade Sapphic tradition in Paris. Though this ultimately failed, Barney was still able to replicate Sappho's role as a connecting force through her salon, and represented herself as such in her sketch of its attendees, which included Vivien.

\section{Conclusions: Rethinking Tradition as Resistance}

\section{Shari Benstock argues in Women of the Left Bank that Natalie Clifford Barney's}

life must be read as one "consciously constructed outside and beyond the dictates of Western culture." 194 It is fitting, then, that Barney's resistance to social restrictions on her gender and sexuality came in the form of re-making the tradition of a poet from antiquity whose desires, Benstock notes, challenged turn-of-the-century social imperatives. ${ }^{195}$

\footnotetext{
192 Barney, Équivoque, 75.

193 See Ellis's discussion of lesbianism and violent crime. Sexual Inversion, 201.

194 Benstock, Women of the Left Bank, 269.

195 Ibid.
} 
Similarly, Benstock states, Vivien "set out to reclaim Sappho from male authors,"196 and that her construction of Lesbos was explicitly matriarchal. 197

Despite the very different ways in which Barney and Vivien lived and died Vivien's life has been described as "a long suicide", ${ }^{198}$ while Barney lived into her nineties ${ }^{199}$ - they both shared an interest in re-making Sappho's tradition and centering it around her relationship to Lesbos and her desire for women. They both also shared a desire to re-create that tradition in turn-of-the-century Paris.

In Questions of Tradition, Mark Salber Phillips and Gordon Schochet re-conceive of tradition as something that can be both descriptive and prescriptive. ${ }^{200}$ Analyzed through this lens, Barney and Vivien's project of re-making Sappho's tradition uses the former category of tradition to resist the latter. By re-making Sappho's tradition and grounding it in her historical character, Barney and Vivien resisted prescriptive discourses that sought to pathologize their gender and sexuality.

Through their rethinking and rewriting of Sappho's historical character and their attempt to re-create Sappho's community of creative women-desiring women at Lesbos in early twentieth century Paris, Natalie Clifford Barney and Renée Vivien reworked Sappho's tradition and continued it in its remade form. They did this by taking what was useful to their project from Sappho's legends and poetry in order to re-make her tradition as one that, at its core, was focused on women's same-gender desire and Sappho's relationship to Lesbos.

\footnotetext{
196 Ibid., 285.

197 Ibid.

198 Ibid., 277. Quoting George Wickes, The Amazon of Letters: The Life and Loves of Natalie Barney (New York, NY: Putnam Publishing Group, 1976), 67. 199 Ibid., 6.

200 Mark Salber Phillips and Gordon Schochet, "Preface" in Questions of Tradition ed. Mark Salber Phillips and Gordon Schochet (Toronto, ON: University of Toronto Press, 2004), $i x-x$.
} 
Barney in particular also represented Sappho's tradition as a connecting force that brought individuals into community with one another, and both she and Vivien entangled Sappho with Lesbos. They both also engaged with well known aspects of her tradition, such as the myth of her death, and both rewrote these legends in order to emphasize Sappho's exclusive love for women and her role as the centre of a community of womendesiring women.

This re-conceptualization took place in a specific historic moment, which informed their mutual interest in Sappho and provided discourses for them to resist through their re-making of Sappho's tradition. This historical moment saw the rise of sexology and its narratives about women's same-gender desire as inherently abnormal and corruptive, ${ }^{201}$ and, simultaneously, a renewed interest in antiquity, particularly among women. Because of this, Barney and Vivien were given both something against which to argue and the tools with which to do so.

By engaging with Sappho and re-making her tradition in a way that featured her love for women and her relationship to Lesbos in a central role, Barney and Vivien resisted discourses that posited them as abnormal and at the fringes of society. They were able to historically ground their desires and were also able to push back against narratives that normalized heterosexuality at the expense of any other desires. Given the rediscovery of Sappho's work and new fragments in the twentieth and twenty-first centuries, it can be speculated that Sappho's tradition also helped cement those of Barney and Vivien.

${ }^{201}$ Krafft-Ebing, Psychopathia Sexualis and Ellis, Sexual Inversion. 


\section{Conclusion}

As we have seen, Marguerite Durand and her fellow journalists at La Fronde, and Natalie Barney and Renée Viven each used their writing to resist restrictive and oppressive norms and discourses in fin-de-siècle Paris. Although neither Durand and La Fronde nor Barney and Vivien have been ignored by scholars, and though both groups of women lived and wrote in Paris around the same time, the scholarship on them has had few points of convergence. Moreover, writing about Barney and Vivien has been dominated by literary scholars, journalists, biographers, and male writers interested in presenting their lives as scandalous "literary gossip."1 This thesis has put these women's efforts into conversation with one another, and it has taken a historical approach to shed new light on how women used writing in order to resist, challenge, and escape restrictions on women and their lives. In this thesis, Durand and La Fronde have been examined alongside Barney and Vivien in order to open new lines of historical inquiry about women, their writing, and resistance. Studying their respective uses of writing in this way further deepens our appreciation for what they were trying to accomplish.

This thesis has argued that La Fronde's content and its role in fin-de-siècle print culture and society is complex and cannot be fit into neat categories. It contained content from a variety of contributors, some of whom disagreed with one another on ideas or tactics. These multiple points of view reflect the often fractious nature of emancipatory and feminist movements at the time. Split along class, religious, and political lines, women in fin-de-siècle Paris were far from a united front. Thus, La Fronde provided

\footnotetext{
${ }^{1}$ Shari Benstock, Women of the Left Bank (Austin TX: University of Texas Press, 1986),10.
} 
women with an opportunity to have their voices invade the traditionally male sector of journalism, and made its readership aware of debates that concerned them. Through this invasion, La Fronde's contributors - including Durand herself - resisted social norms that sought to relegate them to the roles of wives or mothers.

Around the same time as Durand and La Fronde were resisting restrictive social roles on one side of Paris, ${ }^{2}$ Natalie Clifford Barney and Renée Vivien were working to remake Sappho's tradition on the other side. In their poetry, plays, and biographies pivoting around Sappho, Barney and Vivien rewrote Sappho's legend as one that focused on her exclusive desire for women and her centrality in Lesbos's community of womendesiring women. In this way, they remade her tradition to fit the goals of their mutual project of reviving a Sapphic community in Paris. Barney and Vivien, who were lovers for nearly a decade, dedicated themselves to attempting to re-create Sappho's community of women in fin-de-siècle Paris. ${ }^{3}$ Although this endeavour failed with to the collapse of their relationship and Vivien's death in 1909, the ways in which Barney and Vivien respectively reworked Sappho's tradition provide important insight into how womendesiring women used their writing to craft identity and community in resistance to sexology's discursive claims about them and their desires.

To conclude, this thesis has illustrated how women in fin-de-siècle Paris used different forms and styles of literary, journalistic, poetic, biographical, and theatrical writing in order to respond to, resist, and challenge norms and discourses that restricted or oppressed them. Analyzing La Fronde and Barney and Vivien's resistances and challenges to these norms and discourses in this way provides a more nuanced

${ }^{2}$ La Fronde (Paris), 1897-1903. La Fronde was published on 14 rue Saint-Georges in the $9^{\text {th }}$ Arrondissement.

${ }^{3}$ Natalie Clifford Barney, Souvenirs Indiscrets (Paris: Flammarion, 1960), 51. 
understanding of the ways in which women used writing as a form of resistance in fin-desiècle Paris. It also brings Barney and Vivien's poetic and theatrical writing into the historical fold by analyzing them in historical context with other writing by women. Putting these women and what they wrote in conversation with one another offers new ways of conceptualizing how writing allowed women to challenge social and scientific discourses that restricted their roles in society.

By juxtaposing La Fronde with Barney and Vivien, this thesis suggests new lines of historical inquiry about the methods of writing that women used and the place they should have in the historical record. Though the woman's novel has been studied in depth, later modern poetry and theatre have not received as much scholarly attention with reference to their historical value. Considering poetry and plays as historical sources on women's resistance in the fin-de-siècle period could open new lines of inquiry into the forms and paths women's resistance through writing took. By examining Barney and Vivien's poetic and theatrical writings as historical sources that provide insight into how they resisted normative discourses, this thesis suggests new potentialities for historical inquiry into how poetry and theatre functioned to challenge authority.

Having put Durand and La Fronde into context and conversation with Barney and Vivien, this thesis also raises new questions about the similarities that existed between other women in fin-de-siècle Paris and have yet to be studied. Analyzing the two groups historically and putting them in conversation with one another contributes to and furthers an ongoing project of broadening investigations of Parisian women and understanding their diverse approaches to feminism, femininity, and writing. 


\section{Bibliography}

\section{Primary Sources:}

La Fronde (Paris), December 1897 - January 1903. Especially:

“La Finance.” La Fronde (Paris), 1897-1903.

“La Bourse.” La Fronde (Paris), 1897-1903.

Abda. "Questions Coloniales.” La Fronde (Paris), 15 February 1898.

Anonymous. “Algérie-Colonies.” La Fronde (Paris), 12 December 1897.

Anonymous. La Fronde (Paris), 8 Deecember 1897.

Belilon, Camille. “Chronique Féministe.” La Fronde (Paris), 15 August 1898.

Bonneval, Marie. “À la Bourse du Travail.” La Fronde (Paris), 19 February 1901.

Bonneval, Marie. “Tribune du Travail.” La Fronde (Paris), 19 June 1902.

D’Ambre, Caroline. “Conclusion.” La Fronde (Paris), 15 June 1898.

D’Ambre, Caroline. "Juifs et gouvernements.” La Fronde (Paris), 15 February 1898.

De Bovet, Marie-Anne. "Ménagères ou Courtisanes?" La Fronde (Paris), 9 December 1897.

De Pratz, Claire. “À l'étranger.” La Fronde (Paris), 9 December 1897.

Dissard, Clotilde. "Le Féminisme en Suisse.” La Fronde (Paris), 15 July 1898.

H.S. “Une cause celebre en Suède.” La Fronde (Paris), 10 December 1897.

Maugeret, Marie. “Le Féminisme Chrétien.” La Fronde (Paris), 11 December 1897.

Milliard, V. “Don de joyeux avènement.” La Fronde (Paris), 10 December 1897. 
Néron, Marie-Louise. "Tailleurs pour les dames.” La Fronde (Paris), 19 February 1901.

Néron, Marie-Louise. “Hôpital d'enfants.” La Fronde (Paris), 10 March 1898.

Néron, Marie-Louise. “Grèves de Mères.” La Fronde (Paris), 15 January 1899.

Osmont. "Pour la Paix.” La Fronde (Paris), 15 May 1899.

Pognon, Maria. "Féminisme.” La Fronde (Paris), 9 December 1897.

Schirmacher, d'Kaethe. "La Tribune: Le Féminisme Allemand.” La Fronde (Paris), 22 December 1897.

Sévérine. "Notes d'une Frondeuse.” La Fronde (Paris), 1897-1903.

Sévérine. "Notes d'une Frondeuse: Questions logiques." La Fronde (Paris), 16 July 1898.

Vincent, V. "Les femmes dans les comités d'admissions à l'exposition de 1900.” La Fronde (Paris), 10 December 1897.

Yamina. "Lettre du Harem.” La Fronde (Paris), 15 November 1898.

Barnes, Djuna. Ladies Almanack. New York, NY: New York University Press, 1992. Reprint.

Barney, Natalie Clifford. Équivoque in Actes et entr'actes, 49-81. Paris: E. Sansot et cie, 1910.

Barney, Natalie Clifford. Douces rivalités in Cinq petits dialogues grècs, 11-40. Paris: La Plume, 1901.

Barney, Natalie Clifford. Sonnet in Cinq petits dialogues grècs, 10. Paris: La Plume, 1901.

Barney, Natalie Clifford. Souvenirs indiscrets. Paris: Flammarion, 1960. 
Ellis, Havelock. Sexual Inversion, 3rd edition. Philadelphia, PA: F.A. Davis Company, 1925. Reprint.

Van Dyke, Henry. "America For Me" in The Poems of Henry Van Dyke New York: Charles Scribner's Sons, 1911. 167.

Vivien, Renée. Sapho: traduction nouvelle avec le texte grec. Paris: Lemerre, 1903.

Bibliothèque National de France: Digitized (Gallica).

Von Krafft-Ebing, Richard Freiherr. Psychopathia Sexualis, ed. V. Robinson. New York, NY: Pioneer Publications, 1939. Reprint.

\section{Secondary Sources:}

Allison, Maggie. "Marguerite Durand and La Fronde: Voicing Women of the Belle Epoque" in A Belle Époque?: Women in French Society and Culture, 1890-1914, ed. D Holmes and C. Tarr, 37-49. New York \& Oxford: Berghahn Books, 2006.

Beccalossi, Chiara. Female Sexual Inversion: Same-Sex Desires in Italian and British Sexology, c. 1870-1920. Houndmills, Basingstoke, Hampshire; New York, NY: Palgrave Macmillan, 2012.

Benstock, Shari. Women of the Left Bank: Paris, 1900-1940. Austin, TX: University of Texas Press, 1986.

Bochenek, Valérie and Jean-Louise Debré. Ces femmes qui on réveillé la France. Paris: Arthème Fayard, 2013.

Brubaker, Rogers. Citizenship and Nationhood in France and Germany. Boston, MA: Harvard University Press, 2009.

Chapman, Jane. Gender, Citizenship and Newspapers: Historical and Transnational Perspectives. Basingstoke, UK: Palgrave Macmillan, 2013.

Choquette, Leslie. "Paris-Lesbos: Lesbian Social Space in the Modern City, 1879-1940," in Proceedings of the Western Society for French History, ed. B. Rothaus, 122-132. Denver, CO: University of Colorado Press, 1999. 
Cross, Máire. “1890-1914: A ‘Belle Époque’ for Feminism?” In A Belle Époque?: Women in French Society and Culture, 1890-1914, ed. D. Holmes and C. Tarr, 23-35. New York \& Oxford: Berghahn Books, 2006.

Engelking, Tama Lea. "Decadence and the Woman Writer: Renée Vivien's Une femme m'apparut" in A Belle Époque?: Women in French Society and Culture 1890-1914, ed. D. Holmes and C. Tarr, 225-237. New York \& Oxford: Berghahn Books, 2006.

Engelking, Tama Lea. "Translating the Lesbian Writer: Pierre Louÿs, Natalie Barney, and 'Girls of the Future Society'," South Central Review 22 (2005): 62-77.

Enstad, Nan. Ladies of Labor, Girls of Adventure: Working Women, Popular Culture, and Labor Politics at the Turn of the Twentieth Century. New York, NY: Columbia University Press, 1999.

Fiske, Shanyn. Heretical Hellenism: Women Writers, Ancient Greece, and the Victorian Popular Imagination. Athens, OH: Ohio University Press, 2008.

Foucault, Michel. The History of Sexuality, Volume 1. New York, NY: Vintage Books, Random House, 1990. Reprint.

Hawthorne, Melanie. "Clans and Chronologies: The Salon of Natalie Barney" in A Belle Époque?: Women in French Society and Culture, 1890-1914, ed. D. Holmes and C. Tarr, 65-78. New York, NY: Berghahn Books, 2006.

Hobsbawm, Eric. "Mass-Producing Traditions: Europe, 1870-1914" in The Invention of Tradition, ed. E. Hobsbawm and T. Ranger, 263-308. Cambridge, UK: Cambridge University Press, 1983.

Hobsbawm, Eric. "Introduction: Inventing Traditions" in The Invention of Tradition, ed. E. Hobsbawm and T. Ranger, 1-14. Cambridge UK: Cambridge University Press, 1983.

Hobsbawm, Eric. Age of Empire: 1875-1914. London, UK: Weidenfeld \& Nicolson Ltd, 2010. Reprint.

Jay, Karla. The Amazon and the Page: Natalie Clifford Barney and Renée Vivien. Bloomington, IN: Indiana University Press, 1988.

Latimer, Tirza True. Women Together/Women Apart: Portraits of Lesbian Paris. New Brunswick, NJ: Rutgers University Press, 2005. 
Lefebvre, Henri. The Production of Space, trans. Donald Nicholson-Smith. Oxford: Blackwell, 1991.

McIntosh Snyder, Jane. Lesbian Desire in the Lyrics of Sappho. New York, NY: Columbia University Press, 1997.

Roberts, Mary Louise. Disruptive Acts: The New Woman in Fin-de-Siècle France. Chicago \& London: University of Chicago Press, 2002.

Rodriguez, Suzanne. Wild Heart: A Life: Natalie Clifford Barney and the Decadence of Literary Paris. New York, NY: Harper Collins, 2009.

Russell, Mona L. Creating the New Egyptian Woman: Consumerism, Education and National Identity, 1863-1922. Basingstoke, UK: Palgrave Macmillan, 2004.

Salber Phillips, Mark and Gordon Schochet. "Preface" in Questions of Tradition, ed. M. Salber Phillips and G. Schochet, $i x-x v$. Toronto, ON: University of Toronto Press, 2004.

Schaffer, Talia. Literature and Culture at the Fin de Siècle. New York, NY: Longman, 2007.

Schaffner, Anna Katharina. Modernism and Perversion. Basingstoke, UK: Palgrave Macmillan, 2012.

Schultheiss, Katrin. "The Dreyfus Affair and History," The Journal of the Historical Society 12 (2012): 189-203.

Souhami, Diana. Wild Girls: Paris, Sappho, and Art: The Lives and Loves of Natalie Barney and Romaine Brooks. London, UK: Weidenfeld \& Nicolson, 2004.

Tiersten, Lisa. Marianne in the Market: Envisioning Consumer Society in Fin-de-Siècle France. Berkeley, Los Angeles, London: University of California Press, 2001.

Trevor-Roper, Hugh. "The Invention of Tradition: The Highland Tradition in Scotland" in The Invention of Tradition, ed. E. Hobsbawm and T. Ranger, 15-41. Cambridge, UK: Cambridge University Press, 1983.

Whitlock, Tammy C. Crime, Gender and Consumer Culture in Nineteenth-Century England. Abingdon-on-Thames, UK: Routledge, 2005. 
Wickes, George. The Amazon of Letters: The Life and Loves of Natalie Barney. New York, NY: Putnam Publishing Group, 1976.

Winning, Joanne. "The Sapphist in the City: Lesbian Modernist Paris and Sapphic Modernity" in Sapphic Modernities: Sexuality, Women, and National Culture ed. L.Doan and J. Garrity, 17-33. New York, NY: Palgrave Macmillan, 2006. 